Article

\title{
Extracts Characterization and In Vitro Evaluation of Potential Immunomodulatory Activities of the Moss Hypnum cupressiforme Hedw.
}

\author{
Tanja M. Lunić ${ }^{1}$, Mariana M. Oalđe ${ }^{2}{ }^{\oplus}$, Marija R. Mandić ${ }^{1}$, Aneta D. Sabovljević ${ }^{2}$, \\ Marko S. Sabovljević ${ }^{2}\left(\mathbb{D}\right.$, Uroš M. Gašić ${ }^{3} \mathbb{D}$, Sonja N. Duletić-Laušević ${ }^{2}$, Bojan Dj. Božić ${ }^{1, *,+(\mathbb{D})}$ \\ and Biljana Dj. Božić Nedeljković ${ }^{1, *, \dagger}$ \\ 1 Institute of Physiology and Biochemistry "Ivan Djaja”, Faculty of Biology, University of Belgrade, \\ 11000 Belgrade, Serbia; b3018_2019@stud.bio.bg.ac.rs (T.M.L.); b3022_2019@stud.bio.bg.ac.rs (M.R.M.) \\ 2 Institute of Botany and Botanical Garden "Jevremovac", Faculty of Biology, University of Belgrade, \\ 11000 Belgrade, Serbia; marianao@bio.bg.ac.rs (M.M.O.); aneta@bio.bg.ac.rs (A.D.S.); \\ marko@bio.bg.ac.rs (M.S.S.); sduletic@bio.bg.ac.rs (S.N.D.-L.) \\ 3 Department of Plant Physiology, Institute for Biological Research "Sinisa Stankovic", National Institute of \\ Republic of Serbia, University of Belgrade, Bulevar Despota Stefana 142, 11060 Belgrade, Serbia; \\ uros.gasic@ibiss.bg.ac.rs \\ * Correspondence: bbozic@bio.bg.ac.rs (B.D.B.); biljana@bio.bg.ac.rs (B.D.B.N.); \\ Tel.: +381-11-303-23-56 (B.D.B.N.) \\ + These authors contributed equally to this study.
}

Academic Editor: Panagiotis Zoumpoulakis

Received: 4 July 2020; Accepted: 19 July 2020; Published: 23 July 2020

\begin{abstract}
Recently, there has been an increasing interest in the chemistry and biological potential of mosses, since a large number of biologically active compounds have been found within these species. This study aimed at examining the chemical composition and immunomodulatory potential (antioxidant, antidiabetic, anti-neuroinflammatory/antineurodegenerative, and antitumor activities) of moss Hypnum cupressiforme Hedw. extracts. Corresponding extracts have been obtained applying Soxhlet extractor. The chemical characterization was performed using spectrophotometric assays and liquid chromatography-mass spectrometry (LC-MS). The extracts were analyzed for antioxidant activity and for inhibitory activities on $\alpha$-glucosidase, $\alpha$-amylase, acetylcholinesterase, and tyrosinase. Additionally, extracts were tested against four cell lines-MRC-5, BV2, HCT-116, and MDA-MB-231—for antitumor and anti-inflammatory activities. Chemical analysis of extracts revealed the presence of flavonoids, phenolic acids, and triterpenoids. Major compounds identified by LC-MS in H. cupressiforme were kaempferol and five phenolic acids: $p$-hydroxybenzoic, protocatechuic, $p$-coumaric, gallic, and caffeic acid. According to biochemical assays the investigated extracts exhibited significant immunomodulatory potential. Significant antiproliferative potential against MDA-MB-231 cells has been observed together with the promising anti-neuroinflammatory application. The obtained data suggest that moss $\mathrm{H}$. cupressiforme is a valuable natural source of biologically active compounds with potential application in the pharmaceutical industry.
\end{abstract}

Keywords: moss extract; Hypnum cupressiforme; antioxidant; anti-neuroinflammatory/ antineurodegenerative; antidiabetic; antitumor activity

\section{Introduction}

Bryophytes belong to the second largest group of plants with an estimated 23,000 species worldwide [1]. They are generally classified into three phyla: Bryophyta (mosses), Marchantiophyta (liverworts), and Anthocerotophyta (hornworts). The phylum Bryophyta consists of six classes 
among which the most abundant is Bryopsida [2]. One of the moss species belonging to this class is Hypnum cupressiforme Hedw. (Hypnaceae, Hypnales), commonly known as the cypress-leaved plait-moss or simply hypnum moss. This moss can be found within almost all continents and terrestrial habitat types. It grows on versatile surfaces like logs, walls, or rocks. This moss is typically $2-10 \mathrm{~cm}$ long and pleurocarpous, with branched stems that are forming dense green mats. H. cupressiforme is a highly polymorphic species with a great number of varieties [3].

The representatives of bryophytes are commonly used in traditional medicine all over the world. A moss belonging to the Hypnaceae family, Taxiphyllum taxirameum, has been used in traditional Chinese medicine for the treatment of various inflammation-related conditions, ulcers, skin injuries, and for the treatment of bleeding [4]. Species from the genus Hypnum were used for stuffing pillows and mattresses [4], which can be related to effects such as influence on sleeping quality and may indicate the antimicrobial effect. There is evidence that $H$. cupressiforme expresses good antimicrobial, antioxidant, and antiproliferative activities [5,6]. Additionally, H. cupressiforme was used in different parts of the world for decoration purposes and costume making [4,7].

The chemistry of bryophytes has been overlooked earlier due to their small dimensions, amount of available material, and difficulties with identification [8]. However, recently, with the development of analytical techniques, the interest in bryophyte chemistry has increased [9]. Studies about bryophyte chemical composition are usually focused on their secondary metabolites, which can be divided into two main groups: polyphenols and lipids [9]. The majority of secondary metabolites from mosses belong to flavonoids, terpenoids, and bibenzyls. In addition, there are also compounds such as fatty acids and acetophenols [10]. It is crucial to emphasize that the quantitative and even qualitative composition of the secondary metabolites may be influenced by the environment. It is therefore important to note that moss used in this study was collected from the Vršačke Planine Mts., that is an independent geomorphological unit in southeastern Banat representing a remnant block of the old Pannonian massif [11] with specific microenvironmental factors (the amount of incident light, the degree of moisture, and the range of temperatures). That is of additional specificity and significance in the study of chemical and biological properties of mosses from this area.

The pharmaceutical industry is constantly developing novel pharmacologically active compounds. Medicinal plants are widely used as alternative therapeutic tools for the prevention or adjuvant therapy of various diseases. Among many other plants, bryophytes are recognized as promising sources of new biologically active compounds $[8,12,13]$. Some of the bryophytes secondary metabolites exhibit diverse biological activities such as cytotoxicity, antimicrobial, antifungal, antitumor, antioxidant, anti-inflammatory, and many others [1,6]. The biological activity of a certain plant extract depends on several factors such as chemical composition and structural configuration of functional groups, but also on potential synergistic or antagonistic interactions between compounds within the extract [14].

The aim of this study was to examine the chemical composition, antioxidant, antidiabetic, anti-neuroinflammatory/antineurodegenerative, and antitumor potential of the moss H. cupressiforme extracts in vitro. Previous studies about the biological potential of $H$. cupressiforme are infrequent, reporting good antimicrobial, antioxidant, and antiproliferative activities of this species [5,6]. Additionally, this is a complex and rather genetically variable species. Therefore, this investigation, to the best of our knowledge, is the first regarding the evaluation of potential biological activities of typical moss H. cupressiforme originated from the unique island low-mountain area, namely, the Vršačke Planine Mts., Serbia.

\section{Results}

\subsection{Extraction and Chemical Characterization}

In order to determine appropriate extraction time, the optimization of extraction was performed. During extraction in Soxhlet apparatus, the absorbance of the ethanolic extract was monitored every $2 \mathrm{~h}$ by UV spectrophotometry (UV-Vis 1700, Shimadzu, Kyoto, Japan). The maximum absorption 
point was reached after $10 \mathrm{~h}$ of extraction. This time was set as the optimum time and was used for all other solvents. Table 1 presents the solvents used for the extraction process and weights of the dry moss and crude extracts (further extract). The percentage of extraction yield ranged from $0.6 \%$ for ethyl acetate extract to $26.3 \%$ for the aqueous one. The aqueous extract was found to have a higher yield in comparison with the other extracts.

Table 1. Extraction yield for Hypnum cupressiforme extracts.

\begin{tabular}{ccccc}
\hline Label & Solvent & Moss Weight $(\mathrm{g})$ & Extract Weight $(\mathrm{g})$ & Yield (\%) \\
\hline E1 & Ethanol $(96 \%)$ & 10 & 0.42 & 4.2 \\
E2 & Water-ethanol (1:1, vol $\%)$ & 10 & 0.80 & 8.0 \\
E3 & Ethyl-acetate & 10 & 0.06 & 0.6 \\
E4 & Water & 7.6 & 2.00 & 26.3 \\
\hline
\end{tabular}

The results of Total Phenolic Content (TPC), Total Phenolic Acid Content (TPAC), Total Flavonoid Content (TFC), Total Flavonol Content (TFlC), and Total Triterpenoid Content (TTC) are presented in Table 2.

Table 2. Chemical characterization of Hypnum cupressiforme extracts.

\begin{tabular}{cccccc}
\hline \multirow{2}{*}{ Samples } & $\begin{array}{c}\text { TPC } \\
\text { (mg GAE/g Extract) }\end{array}$ & $\begin{array}{c}\text { TPAC } \\
\text { (mg CAE/g Extract) }\end{array}$ & $\begin{array}{c}\text { TFC } \\
\text { (mg QE/g Extract) }\end{array}$ & $\begin{array}{c}\text { TFIC } \\
\text { (mg QE/g Extract) }\end{array}$ & $\begin{array}{c}\text { TTC } \\
\text { (mg UAE/g Extract) }\end{array}$ \\
\hline E1 & $6.25 \pm 0.48$ & $67.41 \pm 6.97$ & $35.00 \pm 1.34$ & ND $^{1}$ & $88.37 \pm 1.55$ \\
E2 & $7.38 \pm 0.34$ & $7.08 \pm 2.36$ & $12.43 \pm 0.49$ & ND & $75.93 \pm 2.97$ \\
E3 & $15.33 \pm 0.95$ & $339.93 \pm 14.03$ & $58.86 \pm 2.82$ & $14.11 \pm 1.33$ & $235.95 \pm 4.09$ \\
E4 & $18.21 \pm 0.73$ & $8.31 \pm 3.48$ & $2.04 \pm 0.29$ & ND & $43.33 \pm 0.86$ \\
\hline
\end{tabular}

1 not detected.

Among the tested extracts, E3 and E4 exhibited the highest TPC values-15.3 and $18.2 \mathrm{mg}$ gallic acid equivalents (GAE) per $g$ of extract. The results of the TPAC analysis indicated that the highest concentration of phenolic acids was present in E3-339.9 mg caffeic acid equivalents (CAE) per $\mathrm{g}$ of extract. Total Flavonoid Content (TFC) analysis of $H$. cupressiforme extracts showed the greatest flavonoid content in E3-58.9 mg quercetin equivalents (QE) per g of extract. Regarding TFlC, it was found that only ethyl acetate extract has a considerable amount of flavonols- $14.1 \mathrm{mg} Q \mathrm{QE} / \mathrm{g}$ extract. Extract E3 was found to possess the highest amount of TTC $-236.0 \mathrm{mg}$ ursolic acid equivalents (UAE) per $g$ of extract. The other three extracts had lower TTC. The results from the determination of total coumarin content indicate that there is no considerable amount of these compounds in any of the investigated extracts (data not shown).

\section{LC-MS Analysis}

To identify the specific chemical profile of all examined moss extracts (E1-ethanolic extract, E2-aqueous-ethanolic extract, E3-ethyl acetate extract, and E4-aqueous extract.), LC-MS chromatography was applied. The analysis confirmed the presence of 14 compounds (Table 3 ), including six phenolic acids: gallic acid, protocatechuic acid, 5-O-caffeoylquinic acid, $p$-hydroxybenzoic acid, caffeic acid, $p$-coumaric acid, and eight flavonoids: quercetin 3-O-rutinoside, quercetin 3-O-glucoside, isorhamnetin 3-O-glucoside, eriodictyol, apigenin, naringenin, kaempferol, and acacetin.

The predominant compounds of E1 extract were kaempferol, p-hydroxybenzoic acid, protocatechuic acid, and $p$-coumaric acid. Phytochemical characteristics of E2 extract proved to be very similar to the ones of the E1 extract. However, concentrations of the compounds in the E2 extract were slightly lower than in the E1 extract. On the contrary, E3 and E4 extracts demonstrated different phenolic profiles, compared to E1 and E2 extracts, but also compared to each other. Compounds with the highest concentrations in E3 extract were $p$-hydroxybenzoic acid and protocatechuic acid, while gallic acid and $p$-coumaric acid were found in lower concentrations. Extract E4 contained 
high concentrations of $p$-hydroxybenzoic and $p$-coumaric acids, followed by protocatechuic, gallic, and caffeic acids.

Table 3. Concentrations (mg/100 g extract) of compounds in investigated extracts of the Hypnum cupressiforme according to the LC-MS analysis.

\begin{tabular}{ccccc}
\hline mg/100 g Extract & E1 & E2 & E3 & E4 \\
\hline Gallic acid & 0.62 & 0.70 & 0.50 & 1.21 \\
Protocatechuic acid & 3.75 & 2.89 & 2.39 & 3.91 \\
5-O-Caffeoylquinic acid & 0.14 & 0.07 & 0.02 & 0.04 \\
p-Hydroxybenzoic acid & 4.56 & 3.17 & 5.78 & 4.62 \\
Caffeic acid & 0.65 & 0.42 & 0.13 & 1.10 \\
Quercetin 3-O-rutinoside & 0.09 & 0.06 & 0.01 & 0.03 \\
p-Coumaric acid & 2.60 & 2.33 & 0.46 & 4.40 \\
Quercetin 3-O-glucoside & 0.27 & 0.21 & 0.02 & 0.04 \\
Isorhamnetin 3-O-glucoside & 0.12 & 0.06 & 0.02 & 0.04 \\
Eriodictyol & 0.13 & 0.11 & 0.05 & 0.07 \\
Apigenin & 0.51 & 0.47 & 0.11 & 0.11 \\
Naringenin & 0.57 & 0.62 & 0.12 & 0.08 \\
Kaempferol & 7.35 & 6.60 & 0.21 & 0.47 \\
Acacetin & 0.21 & 0.15 & 0.09 & 0.02 \\
\hline
\end{tabular}

\subsection{Biochemical Analysis of Moss Extracts}

\subsubsection{Evaluation of Antioxidant Activity}

The radical scavenging activity of moss extracts, measured with 2,2-diphenyl-1-picrylhydrazyl (DPPH) assay, was lower than the activity of all standard substances. According to the results, E3 and E4 extracts at the concentration of $1000 \mu \mathrm{g} / \mathrm{mL}$ had moderate scavenging activity (23.8 and $19.2 \%$, respectively) compared to standard substances 3,5-di-tert-butyl-4-hydroxytoluene (BHT), 2-tert-butyl-4-hydroxyanisole (BHA), and ascorbic acid (84.1, 85.2, and 88.1\%, respectively). The other extracts had low or no scavenging activity (Table S1). Considering the total reducting power (TRP) assay, the moss extracts examined in this research showed no considerable activity compared to standard substances (Table S1).

The results of the $\beta$-carotene bleaching assay are shown in Figure $1 \mathrm{~A}$. According to the results, E3 and E4 extracts at the concentrations of 100, 50, and $10 \mu \mathrm{g} / \mathrm{mL}$ displayed significant $\beta$-carotene bleaching inhibitory activities compared with the same concentrations of standard substance ascorbic acid. The percentage of inhibition of these extracts was approximately four fold higher than the standard substance ascorbic acid.

The activity of the same extracts at the concentrations of 1000 and $500 \mu \mathrm{g} / \mathrm{mL}$ was similar to the activity of ascorbic acid at the same concentrations. According to the results, E3 and E4 extracts have shown high inhibition percentage of $\beta$-carotene bleaching compared to ascorbic acid. In comparison with BHT and BHA, E3 and E4 extracts have shown moderate activity. Extracts E1 and E2 have shown low to moderate inhibitory activity compared with the standard substances. 

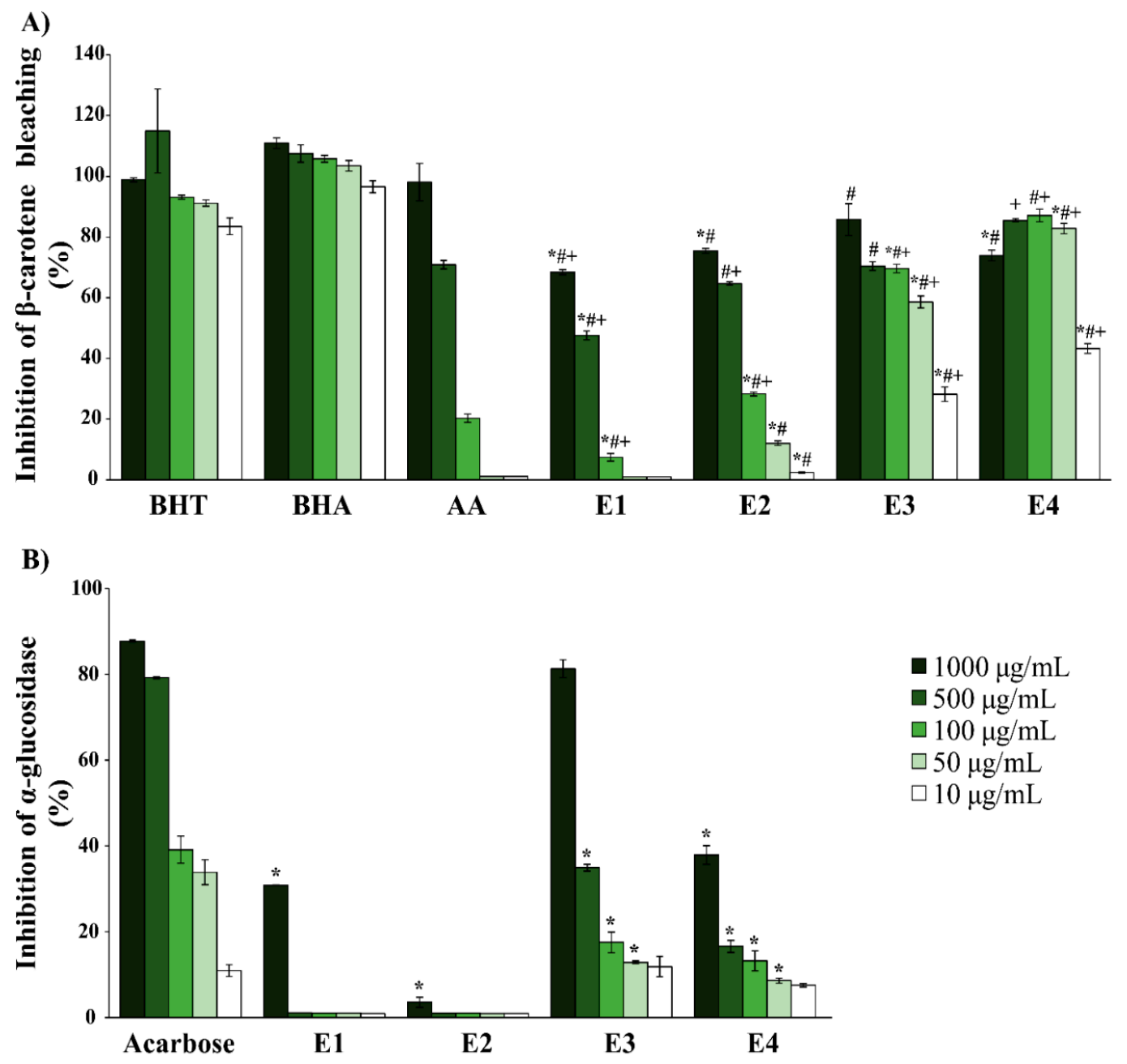

Figure 1. Biochemical analysis of Hypnum cupressiforme extracts as (A) antioxidant and (B) antidiabetic agents. The results are expressed as the mean \pm standard error from an experiment performed in triplicate $\left(\#,+,{ }^{*} p<0.05\right.$ different moss extracts vs. different standard substances. Symbols \# and + were used for standards BHA and AA (ascorbic acid), while * was used for all the other standards).

\subsubsection{Evaluation of Antidiabetic Activity}

Considering $\alpha$-amylase inhibitory activity, the results have shown that the investigated extracts do not possess inhibitory activity against the $\alpha$-amylase enzyme, compared to acarbose (Table S2). The results of $\alpha$-glucosidase inhibitory activity (Figure 1B), however, have shown that the investigated extracts possess certain inhibitory potential against the $\alpha$-glucosidase enzyme. The most active was the E3 extract, followed by the E4 extract. Both of the extracts have shown a similar percentage of inhibition to the standard substance at the concentration of $10 \mu \mathrm{g} / \mathrm{mL}$. According to these results, the E3 extract has shown high inhibition of $\alpha$-glucosidase, while the E4 extract exhibited moderate inhibition of this enzyme. Nevertheless, it is important to point out that both extracts displayed high inhibition properties at the lowest tested concentration $(10 \mu \mathrm{g} / \mathrm{mL})$.

\subsubsection{Evaluation of Antineurodegenerative Activity}

The results for the inhibition of acetylcholinesterase (AChE) and tyrosinase are presented in Figure 2, respectively.

The highest AChE inhibition was achieved with E3 and E4, followed by E2 and E1 extracts. Although galantamine inhibited AChE in a concentration-dependent manner, the extracts performed the strongest activity at $10 \mu \mathrm{g} / \mathrm{mL}$, except the E3 extract which performed the strongest activity at the highest 
tested concentration $(1000 \mu \mathrm{g} / \mathrm{mL})$, followed by the lowest tested concentration $(10 \mu \mathrm{g} / \mathrm{mL})$. Galantamine did not show inhibition of AChE at the concentration of $10 \mu \mathrm{g} / \mathrm{mL}$, while the extracts at the same concentration inhibited the enzyme. According to the obtained results, extracts have shown significantly higher inhibition activity at lower concentrations, when compared to the standard substance.

The evaluation of tyrosinase inhibitory effects showed that all four of the investigated moss extracts exhibit a high percentage of tyrosinase inhibition when compared to kojic acid. At the lowest applied concentration $(10 \mu \mathrm{g} / \mathrm{mL})$, all of the investigated extracts exhibited approximately 2.5-fold higher percentages of inhibition than kojic acid. Moreover, all investigated extracts at the remainingconcentrations $(50,100,500$, and $1000 \mu \mathrm{g} / \mathrm{mL})$ exhibited similar or even higher inhibition activity than kojic acid at the same concentrations.
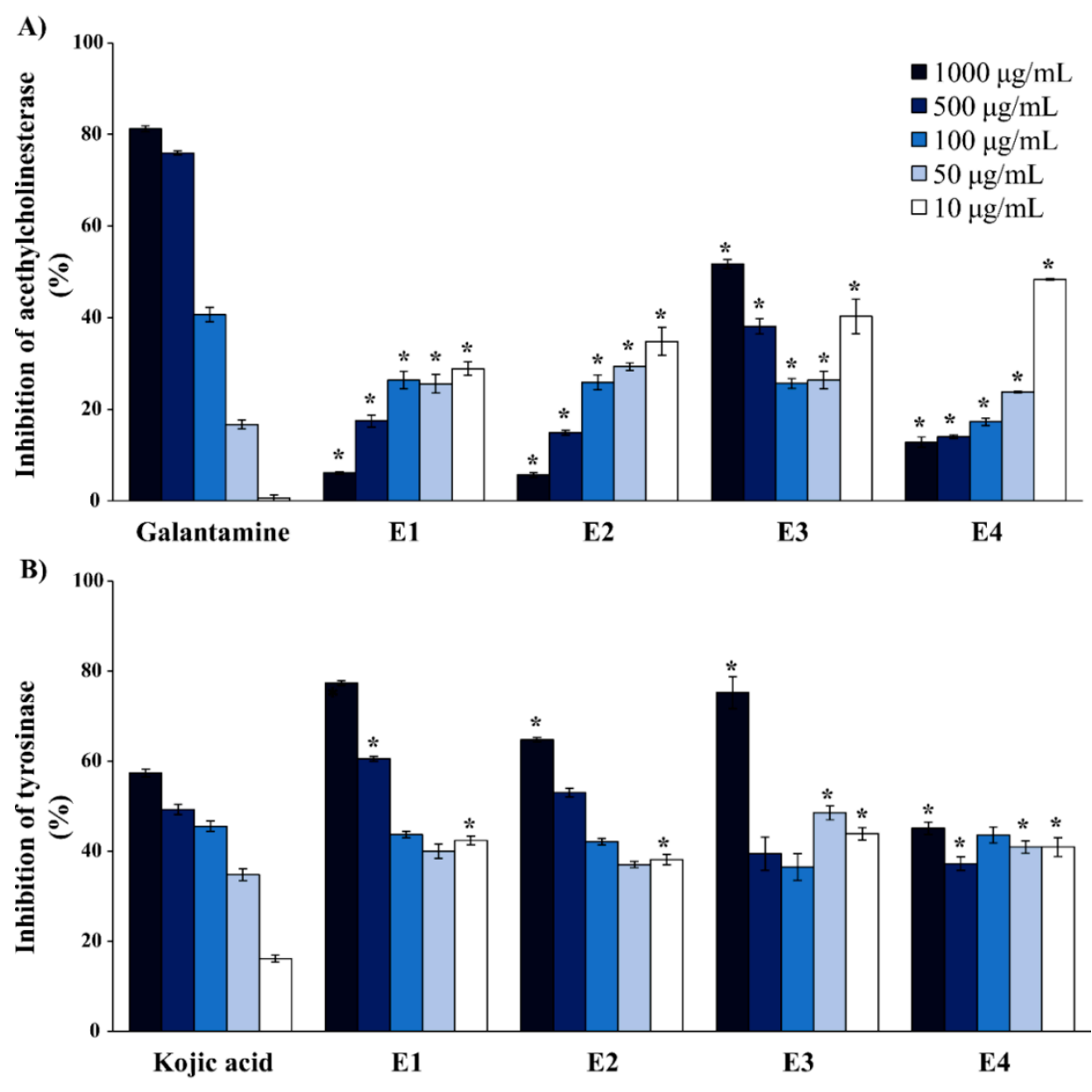

Figure 2. Biochemical analysis of Hypnum cupressiforme extracts as (A) antiacetylcholinesterase and (B) antityrosinase agents. The results are expressed as the mean \pm standard error from an experiment performed in triplicate ${ }^{*} p<0.05$ different moss extracts vs. different standard substances).

\subsection{Immunomodulatory Activities of the Extracts}

\subsubsection{Evaluation of Biocompatibility of Hypnum cupressiforme Extracts (MTT Assay)}

The effect of investigated moss extracts on the proliferation potential of the normal human fibroblast cell line, MRC-5, during $24 \mathrm{~h}$ was measured by the 3-(4,5-dimethylthiazol-2-yl)-2,5-diphenyltetrazolium bromide (MTT) test. This test was used to estimate the biocompatibility of the extracts. The results have shown statistically significant biocompatibility of E1, E2, and E3 extracts (Table S3). Biocompatibility is expressed as a high percentage of viable normal human fibroblasts after the treatment with investigated moss extracts for $24 \mathrm{~h}$. The viability of MRC-5 cells after the treatment with all moss extracts was 
higher than $85 \%$. This biocompatibility analysis demonstrates that the tested extracts do not exhibit any nonspecific toxic effect to normal human fibroblast cells, thus qualifying them as suitable for further investigation in the in vitro model systems for the treatment of some pathological conditions in humans.

\subsubsection{Anti-Neuroinflammatory Potential of Hypnum cupressiforme Extracts}

Due to the good biocompatibility of the investigated extracts and potent anti-inflammatory activity of different moss extracts shown in the existing literature [1,15], the anti-neuroinflammatory activity of the investigated extracts against microglia cell line BV2 has been tested. The results are presented in Figure 3.

A) $\square$ MDA-MB-231 cell line Cell proliferation $\quad \square$ BV2 cell line
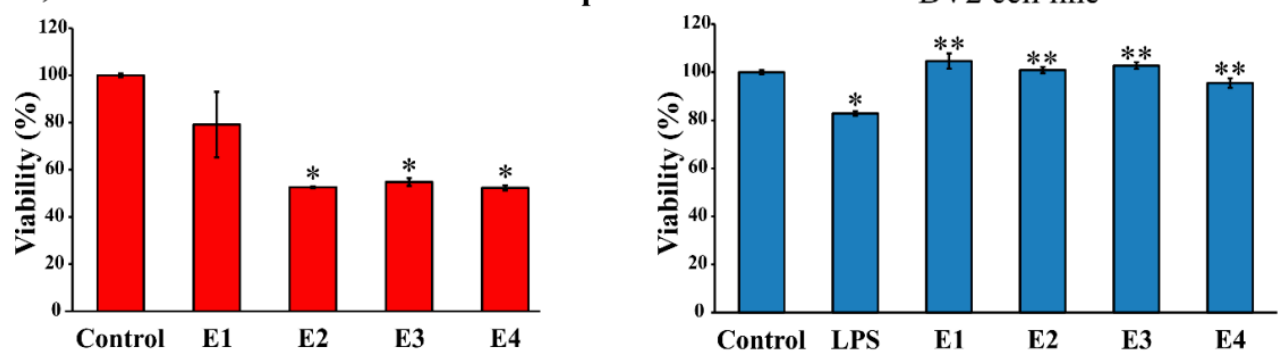

B)

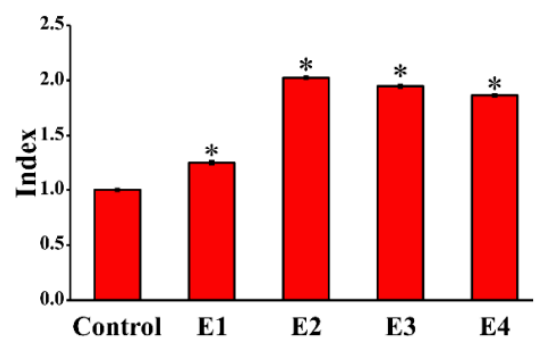

ROS production

C)
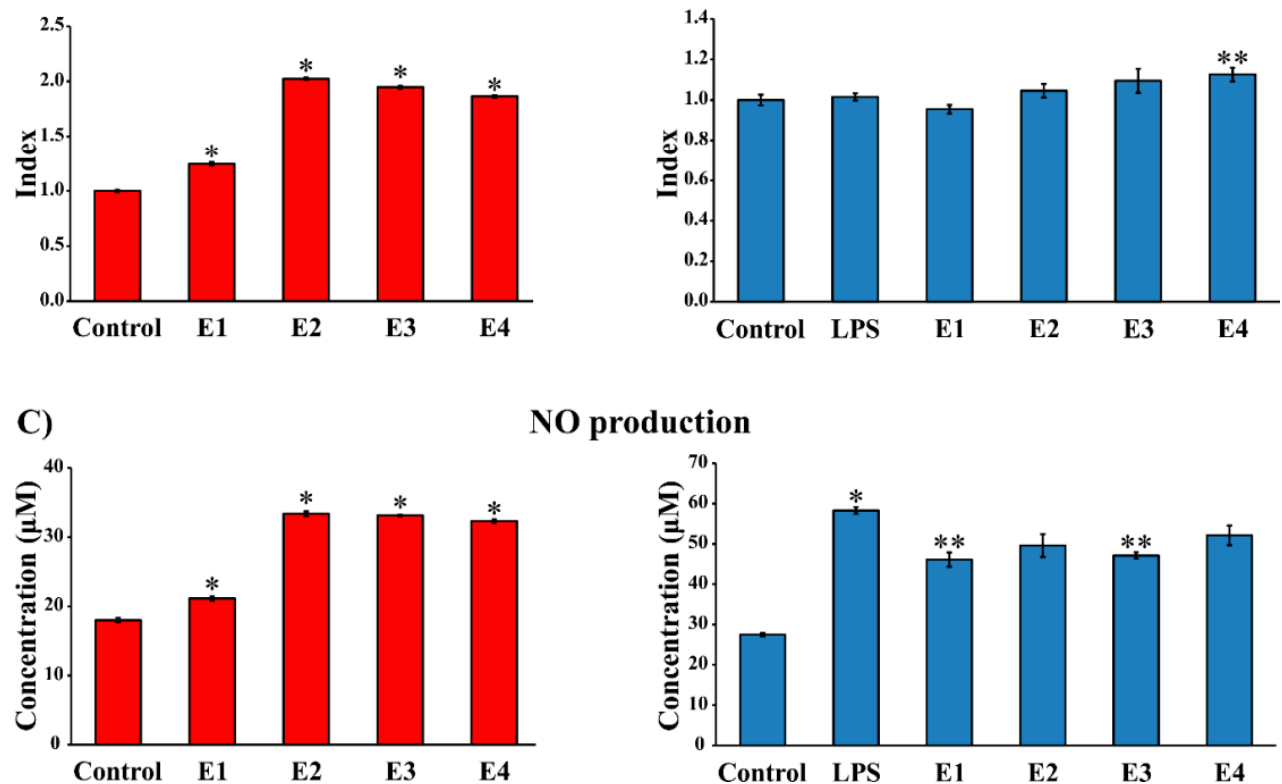

NO production

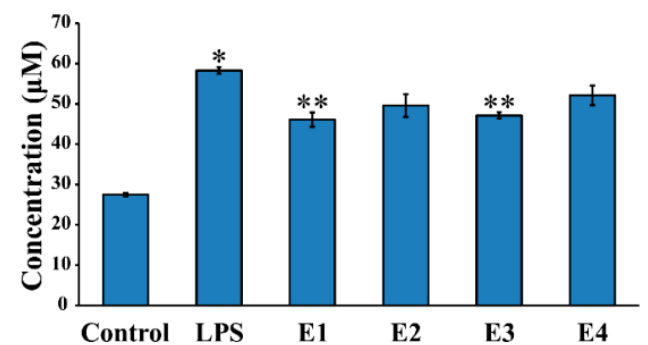

Figure 3. Immunomodulatory potential of Hypnum cupressiforme extracts (final concentration $10 \mu \mathrm{g} / \mathrm{mL}$ ) on (A) cell proliferation, (B) ROS production, and (C) NO production. The results are expressed as mean \pm standard error of a representative experiment performed in quadruplicate. $\left({ }^{*} p<0.05\right.$ different moss extracts and LPS-stimulated control cells vs. non-stimulated control cells; ${ }^{* *} p<0.05$ different moss extracts vs. only LPS-stimulated control cells).

The viability of BV2 microglia cells was evaluated using MTT assay (Figure 3A, right). The results have shown that, compared with the control cells, lipopolysaccharide (LPS) significantly reduced the viability of BV2 cells. Furthermore, treatment with all investigated moss extracts has led to a significant recovery of the viability of LPS-stimulated BV2 cells.

The potential of all moss extracts to modulate reactive oxygen species (ROS) and nitric oxide (NO) production was further evaluated, as significant microglia inflammatory mechanisms. The treatment 
with moss extracts E1, E2, and E3 did not affect the production of superoxide anion radical $\left(\mathrm{O}_{2}^{-}\right)$by BV2 cells, while E4 extract increased the production of ROS in these cells, compared to untreated cells (Figure 3B, right).

The results presented in Figure 3C, right, show that $H$. cupressiforme extracts lead to a decrease in NO production of LPS-stimulated BV2 cells. Extracts E1 and E3 significantly inhibited NO production of LPS-treated BV2 cells measured by nitrite level in cell-free supernatants. This indicates that extracts E1 and E3 have the potential to suppress high NO production, which is an important inflammatory mechanism mediated by inflammatory microglia.

\subsubsection{Antiproliferative Potential of Hypnum cupressiforme Extracts}

According to the good biocompatibility of the investigated extracts and potent antitumor activity of different moss extracts shown in the existing literature $[6,16]$, the antiproliferative activity of the investigated extracts against cancer cell lines, HCT-116 and MDA-MB-231, has been tested.

The data presented in Figure 3A, left, shows that the investigated moss extracts exhibit potent and selective antiproliferative activity against human breast cancer cell line MDA-MB-231. Extracts E2, E3, and E4 showed statistically significant inhibition of proliferation compared to untreated cells (control). On the other hand, against human colon cancer cell line HCT-116, the tested moss extracts did not express an antiproliferative effect (Table S4).

In the nitro blue tetrazolium (NBT) assay, the effects of $H$. cupressiforme extracts on superoxide anion radical $\left(\mathrm{O}_{2}^{-}\right)$production by HCT-116 and MDA-MB-231 cells after $24 \mathrm{~h}$ have been evaluated.

All of the investigated moss extracts have led to a significant increase in $\mathrm{O}_{2}{ }^{-}$production by MDA-MB-231 cells, compared to the production of control cells (Figure 3B, left). Extracts E2, E3, and E4 displayed a higher increase in $\mathrm{O}_{2}{ }^{-}$production than extract E1. However, the investigated extracts did not express any effect on ROS production by HCT-116 cells (Table S4).

Further antiproliferative potential was evaluated through the effect of extracts on nitrite concentration in supernatants of HCT-116 and MDA-MB-231 cells, tested by Griess assay. The concentration of nitrites was used as an indicator of the nitric oxide (NO) level in the investigated cell-free supernatants.

Treatment with moss extracts significantly increased the production of NO by MDA-MB-231 cells, compared to the level of NO in supernatants of untreated cells (Figure 3C, left). As in the case of the impact of moss extracts on ROS production, the investigated extracts did not express an effect on NO production by HCT-116 cells (Table S4).

\section{Discussion}

In the present paper, the focus was on the chemical characterization as well as on antioxidant, antidiabetic, anti-neuroinflammatory/antineurodegenerative, and antitumor effects of four extracts (ethanolic, aqueous-ethanolic, ethyl acetate, and aqueous) of H. cupressiforme from Vršačke Planine Mts. Nature Park, Serbia.

The chemical characterization of moss extracts was performed using spectrophotometric assays (total phenolic, total phenolic acid, total flavonoid, total flavonol, total triterpenoid, and total coumarin contents) and liquid chromatography coupled to mass spectrometry (LC-MS). Literature data of the chemical composition of $H$. cupressiforme are scarce, reporting the presence of n-alkanes, triglycerides, and sterols [17]. Moreover, the isolation of several new to science flavonoid constituents (five new biflavonoids and a 3'-phenylaromadendrin) from this moss has been previously reported [17,18]. Based on the results of spectrophotometric assays, it can be concluded that the highest concentration of the investigated secondary metabolites of $H$. cupressiforme was obtained when ethyl acetate was used as solvent. A previous report [12] on the total phenolic content in H. cupressiforme ethanolic extract revealed a lower concentration of phenols than the onefound in the current study. The content of phenolic compounds in a certain plant depends on several factors such as substrate type; altitude; climate; as well as habitat, environmental condition, or geo-/geno-type [19], which could have influenced the 
differences in the obtained phenolic contents of the extracts. Using LC-MS analysis made it possible to identify 14 phenolic compounds in H. cupressiforme extracts. The major phenolic compounds present in this moss were kaempferol and five phenolic acids: $p$-hydroxybenzoic, protocatechuic, $p$-coumaric, gallic acid, and caffeic acid. These compounds were distributed unevenly among the investigated moss extracts, leading to the conclusion that they have different solubility in the used solvents. The presence of kaempferol in H. cupressiforme has already been reported earlier [18]. Some of the compounds identified in $H$. cupressiforme by LC-MS, including $p$-hydroxybenzoic, 5-O-caffeoylquinic, caffeic, $p$-coumaric, protocatechuic acids, and apigenin, were previously revealed in other moss species [9].

The chemical characterization of $H$. cupressiforme extracts presented in this study has shown that various phenolic acids, flavonoids, and terpenoids can be found in this moss. These compounds exhibit a range of biological activities and can be useful in treating various pathological conditions in humans [1,16], so further part of this research was based on the evaluation of antioxidant, antidiabetic, anti-neuroinflammatory/antineurodegenerative, and antitumor potential of the investigated extracts.

The examined moss extracts showed low radical scavenging activity compared to standard substances evaluated by the DPPH method. A previous study on radical scavenging activity demonstrated high antioxidant activity of H. cupressiforme methanolic extract [6]. This discrepancy in the obtained results could be explained by different extraction solvent and extraction procedure overall, different radical final concentration, or contrasting ecological conditions of the growth site such as season and climate [20]. For instance, it has been shown that the content of secondary metabolites in mosses depends on the season, with the greatest number of biochemical features manifested in the summer [21]. The probable explanation is that biological activities in mosses during summer are more intense than during other seasons, with more protective substances that help tolerate droughts. The moss samples examined in this study were collected during springtime, so it may be expected that they show different potential in terms of some biochemical features, such as radical scavenging activity.

Regarding radical scavenging activity, it is known that the most effective compounds are phenols, which are capable of donating a hydrogen atom from their hydroxyl group [22]. Although mosses are rich in phenolic compounds, their radical scavenging activity seems to be lower than that in vascular plants. In vascular plants, the phenolic and flavonoid contents usually directly correlate with the radical scavenging capacity of the plant [23]. However, in mosses, there is no direct correlation between these terms [9]. This may be the reason why the investigated extracts did not exhibit high radical scavenging activity despite the presence of phenolic compounds in them. Furthermore, numerous triterpenoids have demonstrated significant radical scavenging activity [24]. The correlation between the triterpenoids in $H$. cupressiforme and its radical scavenging activity needs to be further investigated.

It has been reported that anthocyanins and flavonols possess high activity in the $\beta$-carotene bleaching test, followed by flavanols and phenolic acids [25]. Some of the compounds that may express this activity are kaempferol, gallic acid, and caffeic acid [25], and they are identified in the investigated $H$. cuppresiforme extracts by LC-MS. Therefore, these compounds may contribute to the $\beta$-carotene bleaching inhibitory activity of the investigated moss. To the best of our knowledge, there is no previous report on the $\beta$-carotene bleaching activity of the investigated extracts of $H$. cupressiforme. The antioxidant activity obtained for ethyl acetate and aqueous extracts in the $\beta$-carotene bleaching method was significant, while the antioxidant activities measured by the DPPH and TRP methods were quite low. One of the main reasons for this result is the fact that these methods are based on different reaction mechanisms. The DPPH assay is based on a hydrogen radical donating to a certain substance, the TRP assay is based on electron transfer between the substrate and tested sample, while the $\beta$-carotene bleaching assay is based on spearing the already present antioxidant [26]. These results clearly demonstrate the significance of applying more than one analytical method when assessing the antioxidant activity of some new extracts.

Diabetes mellitus (DM) is a chronic disease characterized by insulin deficiency and/or insulin insensitivity which leads to chronic hyperglycemia and disturbance of carbohydrate, lipid, and protein metabolism. One of the therapeutic approaches for DM therapy is inhibition of carbohydrate 
hydrolyzing enzymes, $\alpha$-amylase and $\alpha$-glucosidase. Although synthetic inhibitors of carbohydrate hydrolyzing enzymes are in clinical use, their prices are usually high and they have many side effects. Inhibitors isolated from medicinal plants are considered as an alternative due to fewer side effects and greater efficiency of these compounds. Phenolic compounds, especially flavonoids, phenolic acids, and tannins, apart from being effective antioxidants, have been reported as potent inhibitors of $\alpha$-glucosidase and $\alpha$-amylase [27]. The mechanism of this inhibition depends on the type of polyphenols, as well as their concentration. Monomeric polyphenols inhibit enzyme activity by blocking the catalytic sites, while polymeric polyphenols can form a non-digestible complex with the enzyme [28]. Some of the compounds previously reported to inhibit $\alpha$-glucosidase and $\alpha$-amylase are gallic, caffeic, 5-O-caffeoylquinic acids, kaempferol, quercetin, naringenin, and apigenin [29]. The presence of these compounds in the examined H. cupressiforme extracts, confirmed by LC-MS, could explain their significant inhibitory effect on $\alpha$-glucosidase and $\alpha$-amylase activity which was noticed in the study. Although studies have shown the antidiabetic potential of bryophytes [1], no previous report has been given on the antidiabetic potential of the $H$. cupressiforme. It has been reported that an ideal inhibitor of $\alpha$-amylase and $\alpha$-glucosidase could exhibit specificity for the respective enzyme, effectively reducing the postprandial hyperglycemia, without showing cytotoxic activity to target cells. Furthermore, a better effect could be achieved if the examined compound would mildly inhibit $\alpha$-amylase and strongly inhibit $\alpha$-glucosidase [30]. The investigated extracts of $H$. cupressiforme have demonstrated these properties and therefore could be considered for potential therapeutic application to delay postprandial hyperglycemia, although further in vivo research is required.

The inhibitory potential of the investigated moss extracts against $\mathrm{AChE}$ and tyrosinase, which are associated with the development of various neurodegenerative disorders that are mostly mediated by neuroinflammation, was evaluated. AChE is an enzyme that catalyzes the breakdown of a neurotransmitter called acetylcholine, thus regulating its levels in the synapses. One of the main characteristics of Alzheimer's disease (AD) is memory loss caused by reduced levels of acetylcholine. Therefore, the inhibition of AChE is an effective therapeutic approach in treating AD [31]. On the other hand, tyrosinase is a key enzyme involved in the production of melanin in both skin and hair and may contribute to neuromelanin formation in the central nervous system. The production and accumulation of neuromelanin and the damage of neurons associated with Parkinson's disease (PD) have been extensively studied [32]. The inhibition of tyrosinase has become a prominent target in drug development and research of PD. Due to high prices and the side effects of current treatment strategies for neurodegenerative diseases, there is an increased need for the development of novel therapeutic strategies [33].

This is the first report on the antineurodegenerative activity of the H. cupressiforme. An opposite dose-response observed in the AChE inhibition assay may be caused by mutual interaction between compounds at higher concentrations, which could prevent their inhibitory potential. Moreover, studies have shown that some extracts show the greatest $\mathrm{AChE}$ inhibitory potential at lower concentrations when occupying only a small number of AChE receptors [34]. The majority of phytochemicals with $\mathrm{AChE}$ and tyrosinase inhibitory potential belong to flavonoids, alkaloids, and terpenoids [35]. Some of the flavonoids identified in the examined $H$. cupressiforme extracts, such as naringenin, apigenin, kaempferol, and quercetin, were previously reported to possess $\mathrm{AChE}$ and tyrosinase inhibitory potential [36]. In addition, some of the phenolic acids present in investigated extracts, such as $p$-hydroxybenzoic, protocatechuic, $p$-coumaric, and caffeic acids, have been investigated for their tyrosinase inhibition potential [37].

Microglia represent a specialized population of macrophages extensively distributed in the brain. They mediate immune responses in the central nervous system and remove damaged neurons and cellular debris through the process of phagocytosis [38]. When microglia are activated, in response to pathogens or brain injury, they can enhance neuroinflammation by secreting various proinflammatory mediators, including $\mathrm{NO}$ and ROS. These molecules are associated with neurodegenerative diseases such as AD, PD, multiple sclerosis, and cerebral ischemia [39]. Therefore, the reduction of 
proinflammatory mediators production by microglia is considered to be an essential therapeutic strategy for the prevention or treatment of these disorders [38].

As the antineurodegenerative effect of analyzed extracts was shown, the survey of the anti-neuroinflammatory potential of the extracts on LPS-stimulated BV2 microglial cells was performed. The obtained results suggest that $H$. cupressiforme extracts possess the ability to diminish the production of NO by activated microglia that participate in the majority of neurodegenerative diseases. Inducible nitric oxide synthase (iNOS) is an enzyme that catalyzes the production of NO. Various compounds from plants have been proven to inhibit the expression of iNOS in LPS-activated macrophages. Most of the herbal medicines reduce iNOS-mediated NO production through the inactivation of nuclear factor-kappa B (NF-kB) [40]. It has been reported that flavonoids exhibit strong inhibitory activity on LPS-induced NO production [41]. Kaempferol, quercetin, and naringenin were among the most efficient flavonoids regarding the inhibition of NO production. Additionally, caffeic acid has also shown potent inhibitory activity on NO production [41]. Some of these compounds, identified in H. cupressiforme extracts by LC-MS, may contribute to the anti-neuroinflammatory activity of this moss. Altogether these anti-neuroinflammatory findings with considerable AChE and tyrosinase inhibitory potentials of these moss extracts highly suggest that the extracts of $H$. cupressiforme may be potential therapeutic candidates for the prevention and treatment of neurodegenerative disorders, although further investigation is necessary to confirm their anti-inflammatory activities.

Antitumor agents are one of the most important research topics in drug development. The successful treatment of several tumor types is still a challenge and there are many research studies focused on finding new therapies with fewer side effects. Plants continue to play a major role in drug discovery due to their antiproliferative and proapoptotic properties [42]. Various studies have reported significant cytotoxic activity in the extracts of bryophytes $[15,16]$. The antitumor activity in the investigated extracts was tested as their ability to inhibit the proliferation of two tumor cell lines, HCT-116 and MDA-MB-231. All of the investigated moss extracts, except ethanolic, exerted strong antiproliferative activity against MDA-MB-231 cells, with an inhibition rate of approximately $50 \%$. On the other hand, there was no significant antiproliferative effect on HCT-116 cells. Based on these results, it can be concluded that $H$. cupressiforme extracts exhibit selectivity in the inhibition of the cell cycle between different tumor cells. This is in line with literature data, where it can be seen that H. cupressiforme methanolic extracts exhibit a strong antiproliferative effect on HeLa cancer cells and a moderate antiproliferative effect on lung cancer A549 cells [6]. An extensive literature survey showed that there is no previous report on the antiproliferative activity against the MDA-MB-231 cell line of H. cupressiforme.

Phenolic compounds and terpenoids possess the ability to prevent tumor cell progression by different antitumor mechanisms [16,43]. Generally, these compounds can modulate the redox status and act on cellular processes such as cell proliferation, differentiation, inflammation, apoptosis, and angiogenesis. They have the ability to regulate cell signal transduction and gene expression, thus controlling tumor development [43]. Flavonoids, among many other compounds, have been investigated for potential antitumor activity. In human breast cancer cell lines, such as MDA-MB-231, flavonoids have been reported to downregulate the expression of mutant p53 protein to almost undetectable levels and to inhibit the production of heat shock proteins [44]. Furthermore, it has been experimentally proven that flavonoids apigenin, quercetin, kaempferol, and quercetin 3-O-rutinoside (rutin) are potent inhibitors of the transcription factor NF- $\mathrm{KB}$, responsible for the activation of many genes involved in cell proliferation, thus acting as antiproliferative agents [44]. Given that the moss extracts investigated in this study contain certain amounts of phenolic compounds and terpenoids, these compounds might contribute to a significant antiproliferative activity of all extracts, except the ethanolic one.

ROS and NO are essential for maintaining cell homeostasis, but can also be involved in the development of different pathologies. The roles of ROS and NO in cancer cells are controversial, with some reports indicating their antitumor potential, while others suggest they have a role in 
tumor promotion $[45,46]$. Tumor cells generally demonstrate a constant increase in the generation of ROS, which in turn makes these cells more vulnerable to further oxidative stress. This biochemical characteristic has been used to selectively kill tumor cells by further elevation of cellular ROS. Increased ROS production in tumor cells may induce cell death through the induction of apoptosis via death signaling pathways [45]. NO was reported to inhibit cell proliferation and induce cell death by affecting apoptosis-related mitochondrial proteins [47]. It was shown that breast cancer cells treated with various apoptotic agents have shown an increased production of NO [48]. All four extracts tested in this study have led to a significant increase in ROS production by breast cancer MDA-MB-231 cells. All examined extracts significantly increased the production of NO by MDA-MB-231 cells, as well. The significant antiproliferative potential of $H$. cupressiforme extracts demonstrated against MDA-MB-231 cells could be mediated via increased ROS and NO production. However, the exact mechanism remains to be further explored.

\section{Materials and Methods}

\subsection{Reagents and Standards}

Acarbose, acetylcholine iodide, and acetylcholinesterase from Electrophorus electricus Linnaeus, 1766, and aluminum chloride $\left(\mathrm{AlCl}_{3}\right)$, ascorbic acid, BHA (2-tert-butyl-4-hydroxyanisole), BHT (3,5-di-tert-butyl-4-hydroxytoluene), protocatechuic acid, 5-O-caffeoylquinic acid, p-hydroxybenzoic acid, caffeic acid, $p$-coumaric acid, quercetin 3-O-rutinoside, quercetin 3-O-glucoside, isorhamnetin 3-O-glucoside, eriodictyol, apigenin, naringenin, kaempferol, acacetin, coumarin, disodium hydrogen phosphate dodecahydrate, DMSO (dimethyl sulfoxide), DPPH (2,2-diphenyl-1-picrylhydrazyl), DTNB (5,5'-dithio-bis(2-nitrobenzoic acid)), Folin-Ciocalteu reagent, galantamine natural for system suitability, gallic acid, iron(III) chloride $\left(\mathrm{FeCl}_{3}\right)$, kojic acid, L-DOPA (3,4-dihydroxy-L-phenylalanine), LPS (lipopolysaccharide), Lugol's solution, MTT (3-(4,5-dimethylthiazol-2-yl)-2,5-diphenyltetrazolium bromide), pNPG (4-nitrophenyl $\beta$-D-glucopyranoside), phosphoric acid, potassium dihydrogen phosphate, quercetin, sodium acetate $\left(\mathrm{CH}_{3} \mathrm{COONa}\right)$, sodium bicarbonate $\left(\mathrm{NaHCO}_{3}\right)$, sodium carbonate anhydrous $\left(\mathrm{Na}_{2} \mathrm{CO}_{3}\right)$, sodium chloride $(\mathrm{NaCl})$, sodium dihydrogen phosphate, sodium hydrogen phosphate, sodium nitrite $\left(\mathrm{NaNO}_{2}\right)$, sodium phosphate monobasic dihydrate, sulfanilamide, sulfanilic acid, Trizma base, tyrosinase from Agaricus bisporus (J.E. Lange) Imbach, ursolic acid, vanillin, $\alpha$-amylase, $\alpha$-glucosidase (from Saccharomyces cerevisiae Meyen ex E.C. Hansen) type I, and $\beta$-carotene were purchased from Sigma-Aldrich, St. Louis, MO, USA. Chloroform, ethanol, glacial acetic acid and hydrochloric acid were obtained from Zorka Pharma, Šabac, Serbia. Sodium molybdate dihydrate $\left(\mathrm{Na}_{2} \mathrm{MoO}_{4} \cdot 2 \mathrm{H}_{2} \mathrm{O}\right)$ was obtained from Dispo-chem, Romsey, UK. Sodium hydroxide $(\mathrm{NaOH})$ was purchased from NRK inženjering, Belgrade, Serbia. Aluminum nitrate nonahydrate $\left(\mathrm{Al}\left(\mathrm{NO}_{3}\right)_{3} \cdot 9 \mathrm{H}_{2} \mathrm{O}\right)$ and potassium acetate $\left(\mathrm{CH}_{3} \mathrm{COOK}\right)$ were obtained from Carlo Erba Reagents, Barcelona, Spain. Dipotassium phosphate, methanol, and perchloric acid were purchased from VWR, Radnor, PA, USA. Lead acetate trihydrate $\left(\mathrm{Pb}\left(\mathrm{C}_{2} \mathrm{H}_{3} \mathrm{O}_{2}\right)_{2} \cdot 3\left(\mathrm{H}_{2} \mathrm{O}\right)\right)$, potassium ferricyanide(III), and trichloroacetic acid were obtained from Superlab, Belgrade, Serbia. Linoleic acid and Tween 40 were purchased from Acros Organics, Geel, Belgium, while 1\% starch solution was purchased from Carl Roth, Karlsruhe, Germany. DMEM (Dulbecco's Modified Eagle Medium), FBS (Fetal Bovine Serum), and PBS (Phosphate-Buffered Saline) were obtained from GIBCO, Invitrogen, Carlsbad, CA, USA. NBT (Nitro Blue Tetrazolium) was obtained from SERVA, Heidelberg, Germany.

\subsection{Plant Material}

\subsubsection{Moss Material Collection}

Moss material was collected in Vršačke Planine Mts. (Serbia) (N45.128208, E21329945, 370 m a.s.1.), from the siliceous rock outcrops within the forest openings in May 2019 (leg./det. M. S. Sabovljevic and 
A. D. Sabovljevic, 11th May 2019; voucher BEOU bryo collection $s / n$ ). Mosses were placed in paper bags and kept at room temperature. The room-dried and cleaned material (i.e., green tips with no older parts and substrate remnants) was then lyophilized and ready for extraction. The whole study flow (except biological evaluation) is presented in Figure 4.

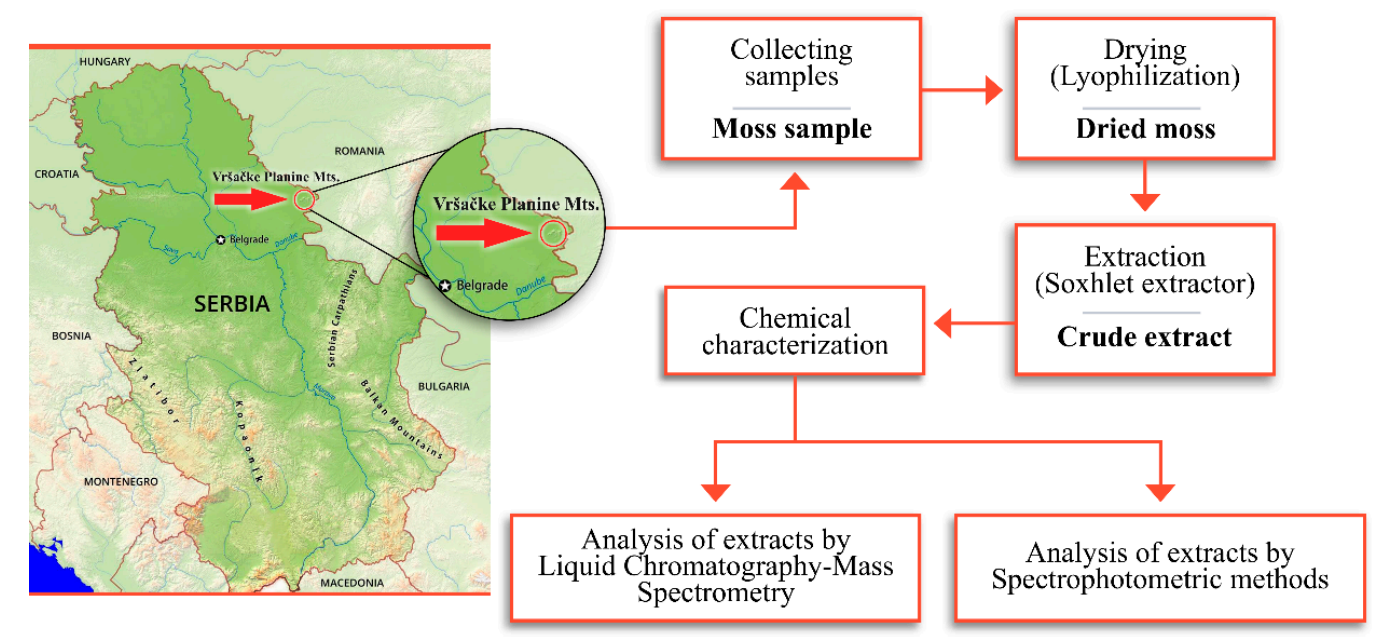

Figure 4. The position of the investigated collection area (Vršačke Planine Mts.) in Serbia with illustrated steps in the preparation and characterization of the extracts.

\subsubsection{Preparation of the Extracts}

The plant material was dried, and the extraction was performed with different solvents in the Soxhlet apparatus for $10 \mathrm{~h}$. Four different solvents were used: $96 \%$ ethanol, a mixture of water and ethanol in 1:1 ratio, ethyl acetate, and water. The extracts were labeled as follows; E1 for ethanolic extract, E2 for aqueous-ethanolic extract, E3 for ethyl acetate extract, and E4 for aqueous extract. The extracts were concentrated in vacuum (Buchi R-210 Rotavapor System, Marshall Scientific, Hampton, NH, USA) and stored at $+4{ }^{\circ} \mathrm{C}$.

\subsection{Chemical Characterization}

\subsubsection{Total Phenolic Content}

Total Phenolic Content (TPC) of the extracts was determined using the Folin-Ciocalteau method [49]. Briefly, $20 \mu \mathrm{L}$ of each extract $(1 \mathrm{mg} / \mathrm{mL})$ was mixed with $100 \mu \mathrm{L}$ of $10 \%$ Folin-Ciocalteu reagent and kept for $6 \mathrm{~min}$ at room temperature. After that, $80 \mu \mathrm{L}$ of $7.5 \%$ sodium carbonate anhydrous was added to the reaction mixture and kept for $120 \mathrm{~min}$ in the dark at room temperature. The absorbance was measured at $740 \mathrm{~nm}$, using Multiskan Sky Thermo Scientific microtiter plate reader, Vantaa, Finland. The negative control contained distilled water instead of the sample. TPC was calculated from the curve equation of gallic acid and the results were expressed as milligrams of gallic acid equivalents per gram of dry extract (mg GAE/g dry extract).

\subsubsection{Total Phenolic Acid Content}

Total Phenolic Acid Content (TPAC) of the extracts was determined using a modified procedure [50]. For the determination of TPAC in extracts, $10 \mu \mathrm{L}$ of extract $(1 \mathrm{mg} / \mathrm{mL})$ was mixed with $20 \mu \mathrm{L}$ of Arnow reagent ( $10 \% w / v$ of sodium molybdate and $10 \% w / v$ sodium nitrite), $20 \mu \mathrm{L} 0.1 \mathrm{M}$ hydrochloric acid, and $20 \mu \mathrm{L} 1 \mathrm{M}$ sodium hydroxide. After adding $100 \mu \mathrm{L}$ of distilled water to the obtained mixture, the absorbance was measured immediately at $490 \mathrm{~nm}$, using Multiskan Sky Thermo Scientific microtiter plate reader, Vantaa, Finland. The control contained $50 \%$ ethanol instead of the sample. TPAC was calculated from the curve equation of caffeic acid in 50\% ethanol. The results were expressed as milligrams of caffeic acid equivalents per gram of dry extract (mg CAE/g dry extract). 


\subsubsection{Total Flavonoid Content}

Determination of Total Flavonoid Content (TFC) was performed by spectrophotometric method [51]. Each well was filled with $50 \mu \mathrm{L}$ of extracts $(1 \mathrm{mg} / \mathrm{mL}), 205 \mu \mathrm{L} 80 \%$ ethanol, $5 \mu \mathrm{L}$ $10 \%$ aluminum nitrate nonahydrate, and $5 \mu \mathrm{L} 1 \mathrm{M}$ potassium acetate solution. After $40 \mathrm{~min}$ of incubation at room temperature, the absorbance was measured at $415 \mathrm{~nm}$, using Multiskan Sky Thermo Scientific microtiter plate reader, Vantaa, Finland. The negative control contained $96 \%$ ethanol instead of the sample. The calibration curve for TFC was made using a quercetin standard solution under the same procedure as earlier described. TFC was calculated from the curve equation of quercetin and the results were expressed as milligrams of quercetin equivalents per gram of dry extract (mg QE/g dry extract).

\subsubsection{Total Flavonol Content}

The Total Flavonol Content (TFIC) of the extracts was determined using a modified procedure [50]. Briefly, $40 \mu \mathrm{L}$ of methanolic solutions of extracts $(1 \mathrm{mg} / \mathrm{mL})$ was mixed with the same volume of aluminum chloride $(20 \mathrm{mg} / \mathrm{mL})$ solution in methanol and $120 \mu \mathrm{L}(50 \mathrm{mg} / \mathrm{mL})$ methanolic solution of sodium acetate. The absorbance of the resulting yellow complex at $440 \mathrm{~nm}$ was read after $2.5 \mathrm{~h}$, using Multiskan Sky Thermo Scientific microtiter plate reader, Vantaa, Finland. The negative control contained $100 \%$ methanol instead of the sample. Series of quercetin in $100 \%$ methanol were prepared for the calibration curve. TFIC was calculated from the curve equation of quercetin and the results were expressed as milligrams of quercetin equivalents per gram of dry extract (mg QE/g dry extract).

\subsubsection{Total Triterpenoid Content}

Total Triterpenoid Content (TTC) was determined according to a previously reported method [52]. Briefly, all extracts were individually dissolved in $100 \%$ methanol at concentrations 1 and $10 \mathrm{mg} / \mathrm{mL}$. Then, $10 \mu \mathrm{L}$ of each of these sample solutions was mixed with $15 \mu \mathrm{L}$ of vanillin-glacial acetic acid solution $(5 \% w / v)$ and $50 \mu \mathrm{L}$ of perchloric acid solution. The sample solutions were incubated for $45 \mathrm{~min}$ at $60^{\circ} \mathrm{C}$ and then cooled to the ambient temperature. The negative control contained $100 \%$ methanol instead of the sample. After the addition of glacial acetic acid $(225 \mu \mathrm{L})$, each sample solution's absorbance was measured at $548 \mathrm{~nm}$, using Multiskan Sky Thermo Scientific microtiter plate reader, Vantaa, Finland. Ursolic acid dissolved in $100 \%$ methanol and was used for making the calibration curve. TTC was calculated from the curve equation of ursolic acid, and the results were expressed as milligrams of ursolic acid equivalents per gram of dry extract (mg UAE/g dry extract).

\subsubsection{Total Coumarin Content}

Total Coumarin Content (TCC) of the extracts was performed according to a slightly modified procedure [53]. Each well was filled with $2 \mu \mathrm{L}$ of extract dissolved in $80 \%$ methanol $(10 \mathrm{mg} / \mathrm{mL}), 8 \mu \mathrm{L}$ of distilled water, and $2 \mu \mathrm{L}$ of lead-acetate solution $(5 \% w / v)$. Another $28 \mu \mathrm{L}$ of distilled water was added to each well, followed by $160 \mu \mathrm{L}$ of hydrochloric acid $(0.1 \mathrm{M})$. The reaction mixture was incubated for $30 \mathrm{~min}$ at ambient temperature. The absorbance was measured at $320 \mathrm{~nm}$, using Multiskan Sky Thermo Scientific microtiter plate reader, Vantaa, Finland. The negative control contained 100\% methanol instead of the sample. Coumarin dissolved in methanol was used for the calibration curve. TCC was calculated from the curve equation of coumarin and the results were expressed as milligrams of coumarin equivalents per gram of the dry extract (mg CE/g dry extract).

\subsubsection{Liquid Chromatography-Mass Spectrometry}

Separation of compounds of interest was performed using a Dionex Ultimate 3000 UHPLC system equipped with a diode array detector (DAD) that was connected to TSQ Quantum Access Max triple-quadrupole mass spectrometer equipped with heated electrospray ionization probe (HESI-II, ThermoFisher Scientific, Bremen, Germany) in negative ionization mode. 
A Syncronis C18 column $(100 \times 2.1 \mathrm{~mm}, 1.7 \mu \mathrm{m}$ particle size $)$ at $40{ }^{\circ} \mathrm{C}$ was used for compound separation: Flow rate was set to $0.3 \mathrm{~mL} / \mathrm{min}$ and the mobile phase consisted of (A) water $+0.1 \%$ formic acid and (B) acetonitrile. Linear gradient program was used as follows; 0.0-1.0 $\mathrm{min} 5 \% \mathrm{~B}, 1.0-14.0 \mathrm{~min}$ from $5 \%$ to $95 \%$ (B), $14.0-14.1 \mathrm{~min}$ from $95 \%$ to $5 \%$ (B), and $5 \%$ (B) for $6 \mathrm{~min}$.

The parameters of the ion source and the other MS data necessary for quantification were as previously described in the literature [54]. ThermoFisher Scientific Xcalibur software (version 2.1) was used for instrument control, data acquisition, and data analysis.

\subsection{Biochemical Assays}

\subsubsection{DPPH Assay}

The scavenging activity of moss extracts was evaluated using DPPH assay [55] with slight modifications. Briefly, $20 \mu \mathrm{L}$ of sample solutions in appropriate solvents (concentrations of 10, 50, 100, 500 , and $1000 \mu \mathrm{g} / \mathrm{mL}$ ) and $180 \mu \mathrm{L}$ of fresh methanolic solution of DPPH (40 $\mu \mathrm{g} / \mathrm{mL})$ were added to each well of a microtiter plate. Methanol dissolved in DPPH solution was used as a negative control. Butylated hydroxytoluene (BHT), butylated hydroxyanisole (BHA), and ascorbic acid were used as positive controls (standards). The absorbance of the reaction mixture was measured after $30 \mathrm{~min}$ in the dark at room temperature at $517 \mathrm{~nm}$, using Multiskan Sky Thermo Scientific Microtiter plate reader, Vantaa, Finland.

The decrease of absorption of DPPH radical at $517 \mathrm{~nm}$ was calculated using the following equation,

$$
\text { Inhibition of DPPH radical }(\%)=[(A c-A s) / A c] \times 100
$$

where $A c$ represents the absorbance of the negative control and $A s$ represents the absorbance of the test samples at different concentrations.

\subsubsection{Total Reducing Power Assay}

The ability of the extracts to reduce iron(III) was assessed by the slightly modified method [56], and following a previous procedure [57]. Briefly, $20 \mu \mathrm{L}$ of each extract in an appropriate solvent (concentrations of $10,50,100,500$, and $1000 \mu \mathrm{g} / \mathrm{mL})$ was mixed with $40 \mu \mathrm{L}$ of phosphate buffer $(0.2 \mathrm{M}$, $\mathrm{pH}$ 6.6) and $40 \mu \mathrm{L}$ of $1 \%$ potassium ferricyanide(III) solution. The mixture was incubated for $20 \mathrm{~min}$ at $45^{\circ} \mathrm{C}$, after which $40 \mu \mathrm{L}$ of trichloroacetic acid $(10 \%, w / v), 40 \mu \mathrm{L}$ of distilled water, and $8 \mu \mathrm{L}$ of $0.1 \%$ iron(III) chloride were added. After an incubation of $10 \mathrm{~min}$ at room temperature, the absorbance was measured at $700 \mathrm{~nm}$ minutes, using Multiskan Sky Thermo Scientific, Vantaa, Finland microtiter plate reader. The negative control was prepared in the same manner as the reaction mixture, with $20 \mu \mathrm{L}$ of appropriate solvent instead of the sample. BHT, BHA, and ascorbic acid were used as positive controls (standards) and data are presented only against ascorbic acid as the same results were obtained. The Total Reducing Power (TRP) of the samples is expressed as $\mu \mathrm{mol}$ of Ascorbic Acid Equivalents (AAE) per gram of dry extract ( $\mu \mathrm{mol} \mathrm{AAE} / \mathrm{g}$ dry extract).

\subsection{3. $\beta$-Carotene Bleaching Assay}

$\beta$-carotene bleaching assay was performed according to a slightly modified procedure [58]. The emulsion was prepared by adding linoleic acid $(6.25 \mu \mathrm{L})$ and Tween $40(50 \mathrm{mg})$ into a solution of $\beta$-carotene in chloroform $(125 \mu \mathrm{L}, 4 \mathrm{mg} / \mathrm{mL})$. Moreover, $125 \mu \mathrm{L}$ of chloroform was added to the prepared emulsion. Chloroform was removed using a rotary evaporator (Buchi rotavapor R-114, Marshall Scientific, Hampton, NH, USA) at $40{ }^{\circ} \mathrm{C}$, after which $25 \mathrm{~mL}$ of distilled water was added with vigorous shaking. The solutions of samples (concentrations of 10, 50, 100, 500, and $1000 \mu \mathrm{g} / \mathrm{mL}$ ) and standards BHT, BHA, and ascorbic acid were prepared in appropriate solvents. Afterward, $200 \mu \mathrm{L}$ of emulsion and $28 \mu \mathrm{L}$ of the test substance (extracts, standards, $100 \%$ methanol - as negative control) were mixed. 
The absorbance was measured immediately $\left(\mathrm{t}_{0}=0 \mathrm{~min}\right)$ and after $2 \mathrm{~h}$ of incubation $\left(\mathrm{t}_{120}=120 \mathrm{~min}\right)$ at 490 nm, using Multiskan Sky Thermo Scientific Microtiter plate reader, Vantaa, Finland.

The antioxidant activity of the samples was evaluated in terms of inhibition of $\beta$-carotene bleaching using the following equation,

$$
\text { Inhibition of } \beta \text {-carotene bleaching }(\%)=\left[\left(A_{120}-C_{120}\right) /\left(C_{0}-C_{120}\right)\right] \times 100
$$

where $A_{120}$ and $C_{120}$ symbolize the absorbances measured after $120 \mathrm{~min}$ for the sample and negative control, respectively, while $C_{0}$ symbolizes the absorbance of the negative control immediately after the addition of all the reaction components.

\subsection{4. $\alpha$-Amylase Inhibition Assay}

In vitro determination of $\alpha$-amylase inhibition activity was performed using the slightly modified Caraway-Somogyi iodine/potassium iodide method, according to Zengin et al. [59]. In brief, $25 \mu \mathrm{L}$ of properly diluted extracts (concentrations of $10,50,100,500$, and $1000 \mu \mathrm{g} / \mathrm{mL}$ ) were mixed with $50 \mu \mathrm{L}$ of $0.5 \mathrm{mg} / \mathrm{mL} \alpha$-amylase enzyme solution. The solutions were prepared by dissolving the extracts and enzyme in sodium phosphate buffer $(0.1 \mathrm{M}$, pH 6.8 with $6 \mathrm{mM}$ sodium chloride). After 10 min of pre-incubation at $37^{\circ} \mathrm{C}, 50 \mu \mathrm{L}$ of $0.2 \%$ starch dissolved in phosphate buffer was added, and incubation continued for another $10 \mathrm{~min}$ at $37^{\circ} \mathrm{C}$. After that, $25 \mu \mathrm{L}$ of $1 \mathrm{M}$ hydrochloric acid was added to terminate the reaction, and $100 \mu \mathrm{L}$ of Lugol's solution was added to visualize the reaction. The absorbance was measured at $630 \mathrm{~nm}$, using Multiskan Sky Thermo Scientific, Vantaa, Finland microtiter plate reader. Acarbose was used as a positive control (standard).

The percentage inhibition of $\alpha$-amylase enzyme activity was calculated according to the following equation,

$$
\text { Inhibition of } \alpha \text {-amylase }(\%)=\left[\left(A s-A c_{1}\right) / A c_{2}\right] \times 100
$$

where $A s$ represents the absorbance of the reaction mixture with the test sample, $A c_{1}$ is the absorbance of enzyme control (contained buffer instead of the sample), and $A c_{2}$ is the absorbance of substrate control (contained buffer instead of enzyme).

\subsection{5. $\alpha$-Glucosidase Inhibition Assay}

Determination of $\alpha$-glucosidase inhibitory activity was performed according to a previously reported method [60]. Briefly, $120 \mu \mathrm{L}$ of extract (concentrations of 10, 50, 100, 500, and $1000 \mu \mathrm{g} / \mathrm{mL}$ ) and $20 \mu \mathrm{L}$ of enzyme solution $(0.5$ units $/ \mathrm{mL})$ in potassium phosphate buffer $(0.1 \mathrm{M}, \mathrm{pH}$ 6.8) were added to microtiter plate and pre-incubated for $5 \mathrm{~min}$ at $37^{\circ} \mathrm{C}$. Moreover, $20 \mu \mathrm{L}$ of $5 \mathrm{mM}$ pNPG as a substrate was added to the mixture and incubation continued for another $20 \mathrm{~min}$ at $37^{\circ} \mathrm{C}$. Finally, the reaction was stopped by adding $80 \mu \mathrm{L}$ of $0.2 \mathrm{M}$ sodium carbonate anhydrous dissolved in a buffer, and the absorbance was measured at $405 \mathrm{~nm}$, using Multiskan Sky Thermo Scientific microtiter plate reader, Vantaa, Finland. Acarbose was used as a positive control (standard).

The percentage of $\alpha$-glucosidase activity inhibition was calculated according to the following equation,

$$
\text { Inhibition of } \alpha \text {-glucosidase }(\%)=[(A c-A s) / A c] \times 100
$$

where $A c$ stands for the absorbance of the negative control (contained buffer instead of the sample), while $A s$ represents the absorbance of the reaction mixture with the test sample.

\subsubsection{Acetylcholinesterase Inhibitory Activity Assay}

Acetylcholinesterase (AChE) inhibitory activity assay was performed according to the slightly modified method [61]. The test reaction mixture was prepared by adding $140 \mu \mathrm{L}$ of sodium phosphate buffer $(0.1 \mathrm{M}, \mathrm{pH} 7.0), 20 \mu \mathrm{L}$ of DTNB, $20 \mu \mathrm{L}$ of sample dissolved in buffer containing $5 \%$ DMSO 
(concentrations of 10, 50, 100, 500, and $1000 \mu \mathrm{g} / \mathrm{mL}$ ), and $20 \mu \mathrm{L}$ of AChE solution ( 5 units $/ \mathrm{mL}$ ) in Tris- $\mathrm{HCl}$ buffer $(20 \mathrm{mM}, \mathrm{pH} 7.5)$. The negative control mixture contained sodium phosphate buffer instead of a sample. After incubation $\left(15 \mathrm{~min}, 25^{\circ} \mathrm{C}\right)$, the colorimetric reaction was initiated with the addition of $10 \mu \mathrm{L}$ of acetylcholine iodide and the absorbance was measured at a wavelength of $412 \mathrm{~nm}$, using a Multiskan Sky Thermo Scientific, Vantaa, Finland microtiter plate reader. Galantamine was used as a positive control (standard).

The percentage of inhibition of $\mathrm{AChE}$ by the sample was determined using the formula,

$$
\text { Inhibition of } \mathrm{AChE}(\%)=[(A c-A s) / A c] \times 100
$$

where $A c$ symbolizes the absorbance of the negative control, while As represents the absorbance of the test sample.

\subsubsection{Tyrosinase Inhibitory Activity Assay}

Tyrosinase inhibitory activity assay was performed according to a slightly modified method [62] using 96-well plates. The test reaction mixture was prepared by adding $80 \mu \mathrm{L}$ of sodium phosphate buffer ( $0.1 \mathrm{M}, \mathrm{pH} 7), 40 \mu \mathrm{L}$ of tyrosinase solution (46 units/L), and $40 \mu \mathrm{L}$ of the sample (concentrations of 10, 50, 100, 500, and $1000 \mu \mathrm{g} / \mathrm{mL}$ ). After adding $40 \mu \mathrm{L}$ of L-DOPA in buffer and incubation (30 min, $25^{\circ} \mathrm{C}$ ), the absorbances were measured at $475 \mathrm{~nm}$, using Multiskan Sky Thermo Scientific, Vantaa, Finland microtiter plate reader. The negative control contained sodium buffer instead of the sample. Kojic acid was used as a positive control (standard).

The percentage of inhibition of tyrosinase activity was determined using the following formula,

$$
\text { Inhibition of tyrosinase }(\%)=[(A c-A s) / A c] \times 100
$$

where $A c$ stands for the absorbance of the negative control and As stands for the absorbance of the test sample.

\subsection{Biological Assays}

\subsubsection{Cell Culture}

Human embryonic lung fibroblast cell line MRC-5, murine microglial cell line BV2, human colon cancer cell line HCT-116, and human breast cancer cell line MDA-MB-231 were used in this study. All cells were obtained from American Tissue Culture Collection (ATCC, Manassas, VA, USA).

All cells were cultivated in DMEM and supplemented with 10\% FBS, $1 \%$ glucose, and $1 \%$ antibiotics (penicillin and streptomycin). The cells were maintained at $37^{\circ} \mathrm{C}$ in a humidified atmosphere containing $5 \% \mathrm{CO}_{2}$. Near-confluent cells $(100 \mu \mathrm{L})$ were seeded in 96-well microplate $(10,000$ per well for MRC-5, BV2, and MDA-MB-231 cells; 50,000 per well for HCT-116 cells). After $24 \mathrm{~h}$ of cell incubation, $100 \mu \mathrm{L}$ of medium containing adequate investigated extract ( $50 \mu \mathrm{L}$ of medium $+50 \mu \mathrm{L}$ of extract) was added in each well of the microplate. For BV2 cells, $100 \mu \mathrm{L}$ of LPS containing the investigated extracts (50 $\mu \mathrm{L}$ of LPS $1 \mu \mathrm{g} / \mathrm{mL}$ culture $+50 \mu \mathrm{L}$ of extract) was added in each well. The incubation was continued for an additional $24 \mathrm{~h}$. Untreated cells were used as control. The treatment concentration $(10 \mu \mathrm{g} / \mathrm{mL})$ was obtained by serial dilution of the stock solution, thus DMSO concentration decreased continuously.

\subsubsection{Determination of Cell Proliferation/Metabolic Viability (MTT Assay)}

The antiproliferative properties of the prepared extracts were tested utilizing the MTT assay [63] after $24 \mathrm{~h}$ of treatment. This colorimetric assay is based on the reduction of a yellow tetrazolium salt to formazan, an insoluble crystalline product with a deep purple color. Viable cells contain $\mathrm{NAD}(\mathrm{P}) \mathrm{H}$-dependent oxidoreductase enzymes which are capable of this reduction.

After $24 \mathrm{~h}$ of cell incubation with extracts, $100 \mu \mathrm{L}$ of medium was removed, and $10 \mu \mathrm{L}$ of MTT solution ( $5 \mathrm{mg} / \mathrm{mL}$ final concentration in PBS) was added to each well and incubated at $37^{\circ} \mathrm{C}$ in $5 \%$ 
$\mathrm{CO}_{2}$ for $3 \mathrm{~h}$. The produced formazan was dissolved by overnight incubation by adding $100 \mu \mathrm{L}$ of SDS- $\mathrm{HCl}$ (10\% SDS in $0.1 \% 1 \mathrm{~N}$ hydrochloric acid). Finally, the reduced MTT was assayed at $540 \mathrm{~nm}$ using a microplate reader (LKB 5060-006, LKB Instruments, Vienna, Austria). The results are expressed as the percentage of viable cells, calculated as the ratio between the absorbance of treated cells and the absorbance of the untreated control multiplied by 100 .

\subsubsection{Determination of Superoxide Anion Radical (NBT Assay)}

The concentration of superoxide anion radical $\left(\mathrm{O}_{2}{ }^{-}\right)$in the sample was determined by the NBT assay [64]. Nitro Blue Tetrazolium (NBT) undergoes reduction by $\mathrm{O}_{2}^{-}$to form diformazan, a dark blue insoluble precipitate. Levels of $\mathrm{O}_{2}{ }^{-}$generated by the tissue can be quantified by measuring the absorbance of blue formazan.

After $24 \mathrm{~h}$ of cell incubation with extracts, $100 \mu \mathrm{L}$ of medium was removed, and $10 \mu \mathrm{L}$ of NBT solution ( $5 \mathrm{mg} / \mathrm{mL}$ in PBS) was added to each well, followed by the cell incubation for $3 \mathrm{~h}$ at $37^{\circ} \mathrm{C}$ in $5 \% \mathrm{CO}_{2}$. To quantify the formazan production, formazan was solubilized in $100 \mu \mathrm{L}$ SDS- $\mathrm{HCl}(10 \%$ SDS in $0.1 \% 1 \mathrm{~N}$ hydrochloric acid). The results are expressed as NBT index, calculated as the ratio between the absorbance of treated cells and the absorbance of the untreated control.

\subsubsection{Determination of Nitrites Level in Supernatants (Griess Assay)}

The determination of nitrites $\left(\mathrm{NO}_{2}{ }^{-}\right)$as an indicator of $\mathrm{NO}$ level was performed using the spectrophotometric method [65]. The Griess reagent consists of two components: $N$-(1-naphthyl) ethylenediamine dihydrochloride in distilled water and $1 \%$ sulfanilamide (or sulfanilic acid) in 5\% phosphoric acid. Equal volumes of the two components were mixed together to form the Griess reagent immediately prior to their application on the plate. The Griess reaction is based on the two-step reaction in which acidified $\mathrm{NO}_{2}{ }^{-}$produces a nitrosating agent which subsequently reacts with sulfanilic acid to produce the diazonium ion. This ion is later coupled to $N$-(1-naphthyl) ethylenediamine to form the chromophoric azo-derivative which absorbs light at $540 \mathrm{~nm}$.

After $24 \mathrm{~h}$ of cell incubation with extracts, $50 \mu \mathrm{L}$ of medium from each well was transferred to an empty microplate. After that, $50 \mu \mathrm{L}$ of prepared Griess reagent was added to each well. After 10 min incubation in the dark, the absorbance was measured at $540 \mathrm{~nm}$ using a microplate reader (LKB 5060-006, LKB Instruments, Vienna, Austria). The concentration of nitrites was calculated from the standard curve for nitrite and expressed in $\mu \mathrm{mol} / \mathrm{L}(\mu \mathrm{M})$.

\subsection{Statistical Analysis}

Statistical analysis was performed using SPSS (IBM SPSS Statistics for Windows, Version 25.0., IBM Corporation, Armonk, NY, USA). Statistical evaluation was carried out by Independent Samples $t$-test. For all comparisons, $p<0.05$ for control vs. extract was considered significant. All measurements were performed at least in triplicate and values are expressed as mean \pm standard error.

\section{Conclusions}

In this study, four extracts of moss $H$. cupressiforme from the Vršačke Planine Mts., Serbia were evaluated for their potential antioxidant, antidiabetic, anti-neuroinflammatory/antineurodegenerative, and antitumor activities. The phytochemical analysis of the extracts has shown the presence of biologically active compounds such as flavonoids, phenolic acids, and triterpenoids distributed unevenly among the extracts. The investigated extracts have shown high antioxidant activity regarding the prevention of $\beta$-carotene bleaching, high tyrosinase inhibitory effect, and high $\alpha$-glucosidase and AChE inhibitory activities at lower tested concentrations. The most potent were ethyl acetate and aqueous extracts. Additionally, ethanolic and ethyl acetate extracts manifested anti-inflammatory potential by reducing the production of NO by LPS-stimulated BV2 cells. All extracts, except the ethanolic one, have shown significant antiproliferative potential against MDA-MB-231 cancer cells, and also satisfying biocompatibility with normal cells. 
Based on the presented data, it can be concluded that moss H. cupressiforme from the Vršačke Planine Mts. (Serbia) is a promising candidate that may be useful in the prevention or treatment of various pathological conditions such as diabetes, Alzheimer's disease, Parkinson's disease, and breast cancer. Further in vitro and in vivo studies should focus on the mechanisms underlying the observed activities, all with the aim of developing new, more effective, green-factory made, and less toxic drugs for potential application in humans.

Supplementary Materials: The following are available online, Table S1: Biochemical analysis of Hypnum cupressiforme extracts as antioxidant agents. Table S2: Biochemical analysis of Hypnum cupressiforme extracts as antidiabetic agents. Table S3: Immunomodulatory potential of Hypnum cupressiforme extracts on MRC-5 cells. Table S4: Immunomodulatory potential of Hypnum cupressiforme extracts on HCT-116 cells.

Author Contributions: Conceptualization, B.D.B. and B.D.B.N.; validation, T.M.L., M.S.S., B.D.B., and B.D.B.N.; formal analysis, T.M.L.; investigation, T.M.L., M.M.O., M.R.M., B.D.B., A.D.S., M.S.S., and U.M.G. (LC-MS); resources, S.N.D.-L. and B.D.B.N.; writing—original draft preparation, T.M.L.; writing-review and editing, T.M.L., A.D.S., M.S.S., S.N.D.-L., B.D.B., and B.D.B.N.; visualization, T.M.L., M.M.O., M.R.M., and B.D.B.; supervision, B.D.B. and B.D.B.N.; project administration, B.D.B.N. All authors have read and agreed to the published version of the manuscript.

Funding: This work was supported by the grant of the Ministry of Education and Science of the Republic of Serbia (Contract numbers: 451-03-68/2020-14/200178 and 451-03-68/2020-14/200007).

Acknowledgments: The authors would like to thank Katarina Milićević, PhD student from the Faculty of Biology, University of Belgrade, for her help in the experiments with cell culture.

Conflicts of Interest: The authors declare no conflicts of interest.

\section{References}

1. Asakawa, Y.; Ludwiczuk, A. Chemical constituents of bryophytes: Structures and biological activity. J. Nat. Prod. 2017, 81, 641-660. [CrossRef] [PubMed]

2. Buck, W.R. Morphology and classification of mosses. Bryophyt. Biol. 2001, 71-123.

3. Vujičić, M.; Sabovljević, A.; Sabovljević, M. Axenically culturing the bryophytes: Establishment and propagation of the moss Hypnum cupressiforme Hedw. (Bryophyta, Hypnaceae) in in vitro conditions. Bot. Serb. 2011, 35, 71-77.

4. Harris, E.S. Ethnobryology: Traditional uses and folk classification of bryophytes. Bryologist 2008, 111, 169-217. [CrossRef]

5. Veljić, M.; Đurić, A.; Soković, M.; Ćirić, A.; Glamočlija, J.; Marin, P. Antimicrobial activity of methanol extracts of Fontinalis antipyretica, Hypnum cupressiforme, and Ctenidium molluscum. Arch. Biol. Sci. 2009, 61, 225-229. [CrossRef]

6. Yayıntaş, O.T.; Yılmaz, S.; Sökmen, M. Determination of antioxidant, antimicrobial and antitumor activity of bryophytes from Mount Ida (Canakkale, Turkey). Indian J. Tradit. Knowl. 2019, 18, 395-401.

7. Nelson, T.C.; Carpenter, I. The use of moss in the decorative industry. Econ. Bot. 1965, 19, 70. [CrossRef]

8. Sabovljević, M.S.; Sabovljević, A.D.; Ikram, N.K.K.; Peramuna, A.; Bae, H.; Simonsen, H.T. Bryophytes-an emerging source for herbal remedies and chemical production. Plant Genet. Resour. 2016, 14, 314-327. [CrossRef]

9. Klavina, L.; Springe, G.; Nikolajeva, V.; Martsinkevich, I.; Nakurte, I.; Dzabijeva, D.; Steinberga, I. Chemical composition analysis, antimicrobial activity and cytotoxicity screening of moss extracts (moss phytochemistry). Molecules 2015, 20, 17221-17243. [CrossRef]

10. Gahtori, D.; Chaturvedi, P. Bryophytes: A potential source of antioxidants. In Bryophytes; IntechOpen: London, UK, 2019.

11. Papp, B.; Sabovljević, M. Contribution to the bryophyte flora of the Vršačke Planine Mts., Serbia. Bot. Serb. 2010, 34, 107-110.

12. Ertürk, Ö.; Sahin, H.; Ertürk, E.Y.; Hotaman, H.E.; Koz, B.; Özdemir, Ö. The antimicrobial and antioxidant activities of extracts obtained from some moss species in Turkey. Herba Pol. 2015, 61, 52-65. [CrossRef]

13. Sabovljevic, A.; Sabovljevic, M. Bryophytes, a source of bioactive and new compounds. Recent Prog. Med. Plants 2008, 22, 9-25. 
14. Aslanbaba, B.; Yilmaz, S.; Yayintas, Ö.T.; Özyurt, D.; Özturk, B.D. Total phenol content and antioxidant activity of mosses from Yenice forest (Ida mountain). J. Sci. Perspect. 2017, 1, 1-12. [CrossRef]

15. Mishra, R.; Pandey, V.K.; Chandra, R. Potential of bryophytes as therapeutics. Int. J. Pharm. Sci. Res. 2014, 5, 3584-3593.

16. Dey, A.; Mukherjee, A. Therapeutic potential of bryophytes and derived compounds against cancer. J. Acute Dis. 2015, 4, 236-248. [CrossRef]

17. Sievers, H.; Burkhardt, G.; Becker, H.; Zinsmeister, H.D. Hypnogenols and other dihydroflavonols from the moss Hypnum cupressiforme. Phytochemistry 1992, 31, 3233-3237. [CrossRef]

18. Asakawa, Y.; Ludwiczuk, A.; Nagashima, F. Chemical constituents of bryophyta. In Chemical Constituents of Bryophytes; Springer: Vienna, Austria, 2013; Volume 95, pp. 563-605.

19. Veličković, J.M.; Dimitrijević, D.S.; Mitić, S.S.; Mitić, M.N.; Kostić, D.A. The determination of the phenolic composition, antioxidative activity and heavy metals in the extracts of Calendula officinalis L. Adv. Technol. 2014, 3, 46-51. [CrossRef]

20. Becker, M.M.; Nunes, G.S.; Ribeiro, D.B.; Silva, F.E.; Catanante, G.; Marty, J.-L. Determination of the antioxidant capacity of red fruits by miniaturized spectrophotometry assays. J. Braz. Chem. Soc. 2019, 30, 1108-1114. [CrossRef]

21. Peters, K.; Gorzolka, K.; Bruelheide, H.; Neumann, S. Seasonal variation of secondary metabolites in nine different bryophytes. Ecol. Evol. 2018, 8, 9105-9117. [CrossRef]

22. Indrianingsih, A.W.; Tachibana, S.; Itoh, K. In vitro evaluation of antioxidant and $\alpha$-glucosidase inhibitory assay of several tropical and subtropical plants. Procedia Env. Sci. 2015, 28, 639-648. [CrossRef]

23. Bakari, S.; Hajlaoui, H.; Daoud, A.; Mighri, H.; Ross-Garcia, J.M.; Gharsallah, N.; Kadri, A. Phytochemicals, antioxidant and antimicrobial potentials and LC-MS analysis of hydroalcoholic extracts of leaves and flowers of Erodium glaucophyllum collected from Tunisian Sahara. Food Sci. Technol. 2018, 38, 310-317. [CrossRef]

24. Eom, H.J.; Kang, H.R.; Kim, H.K.; Jung, E.B.; Park, H.B.; Kang, K.S.; Kim, K.H. Bioactivity-guided isolation of antioxidant triterpenoids from Betula platyphylla var. japonica bark. Bioorg. Chem. 2016, 66, 97-101. [CrossRef]

25. Fukumoto, L.; Mazza, G. Assessing antioxidant and prooxidant activities of phenolic compounds. J. Agric. Food Chem. 2000, 48, 3597-3604. [CrossRef] [PubMed]

26. Aminjafari, A.; Miroliaei, M.; Angelova, V.T.; Emamzadeh, R.; Djukic, M.M.; Djuric, A.; Saso, L. Antioxidant activity and protective role on protein glycation of synthetic aminocoumarins. Electron. J. Biotechnol. 2016, 19, 43-48. [CrossRef]

27. Lin, D.; Xiao, M.; Zhao, J.; Li, Z.; Xing, B.; Li, X.; Kong, M.; Li, L.; Zhang, Q.; Liu, Y. An overview of plant phenolic compounds and their importance in human nutrition and management of type 2 diabetes. Molecules 2016, 21, 1374. [CrossRef] [PubMed]

28. Kan, L.; Oliviero, T.; Verkerk, R.; Fogliano, V.; Capuano, E. Interaction of bread and berry polyphenols affects starch digestibility and polyphenols bio-accessibility. J. Funct. Foods 2020, 68, 103924. [CrossRef]

29. Kalita, D.; Holm, D.G.; LaBarbera, D.V.; Petrash, J.M.; Jayanty, S.S. Inhibition of $\alpha$-glucosidase, $\alpha$-amylase, and aldose reductase by potato polyphenolic compounds. PLOS ONE 2018, 13. [CrossRef] [PubMed]

30. Krentz, A.J.; Bailey, C.J. Oral antidiabetic agents. Drugs 2005, 65, 385-411. [CrossRef]

31. Ahmed, F.; Ghalib, R.M.; Sasikala, P.; Ahmed, K.M. Cholinesterase inhibitors from botanicals. Pharm. Rev. 2013, 7, 121-130. [CrossRef]

32. Carballo-Carbajal, I.; Laguna, A.; Romero-Giménez, J.; Cuadros, T.; Bové, J.; Martinez-Vicente, M.; Parent, A.; Gonzalez-Sepulveda, M.; Peñuelas, N.; Torra, A. Brain tyrosinase overexpression implicates age-dependent neuromelanin production in Parkinson's disease pathogenesis. Nat. Commun. 2019, 10, 1-19. [CrossRef]

33. Hussain, R.; Zubair, H.; Pursell, S.; Shahab, M. Neurodegenerative diseases: Regenerative mechanisms and novel therapeutic approaches. Brain Sci. 2018, 8, 177. [CrossRef] [PubMed]

34. Owokotomo, I.; Ekundayo, O.; Abayomi, T.; Chukwuka, A. In-vitro anti-cholinesterase activity of essential oil from four tropical medicinal plants. Toxicol. Rep. 2015, 2, 850-857. [CrossRef] [PubMed]

35. Cespedes, C.L.; Balbontin, C.; Avila, J.G.; Dominguez, M.; Alarcon, J.; Paz, C.; Burgos, V.; Ortiz, L.; Peñaloza-Castro, I.; Seigler, D.S. Inhibition on cholinesterase and tyrosinase by alkaloids and phenolics from Aristotelia chilensis leaves. Food Chem. Toxicol. 2017, 109, 984-995. [CrossRef] [PubMed]

36. Neagu, E.; Paun, G.; Albu, C.; Radu, G.-L. Assessment of acetylcholinesterase and tyrosinase inhibitory and antioxidant activity of Alchemilla vulgaris and Filipendula ulmaria extracts. J. Taiwan Inst. Chem. Eng. 2015, 52, 1-6. [CrossRef] 
37. Zolghadri, S.; Bahrami, A.; Hassan Khan, M.T.; Munoz-Munoz, J.; Garcia-Molina, F.; Garcia-Canovas, F.; Saboury, A.A. A comprehensive review on tyrosinase inhibitors. J. Enzym. Inhib. Med. Chem. 2019, 34, 279-309. [CrossRef]

38. Jung, W.K.; Lee, D.Y.; Park, C.; Choi, Y.H.; Choi, I.; Park, S.G.; Seo, S.K.; Lee, S.W.; Yea, S.S.; Ahn, S.C. Cilostazol is anti inflammatory in BV2 microglial cells by inactivating nuclear factor kappaB and inhibiting mitogen activated protein kinases. Br. J. Pharm. 2010, 159, 1274-1285. [CrossRef]

39. Gonzalez-Scarano, F.; Baltuch, G. Microglia as mediators of inflammatory and degenerative diseases. Annu. Rev. Neurosci. 1999, 22, 219-240. [CrossRef]

40. Kang, C.-H.; Choi, Y.H.; Moon, S.-K.; Kim, W.-J.; Kim, G.-Y. Quercetin inhibits lipopolysaccharide-induced nitric oxide production in BV2 microglial cells by suppressing the NF- $\mathrm{KB}$ pathway and activating the Nrf2-dependent HO-1 pathway. Int. Immunopharmacol. 2013, 17, 808-813. [CrossRef]

41. Jeong, E.J.; Yang, H.; Kim, S.H.; Kang, S.Y.; Sung, S.H.; Kim, Y.C. Inhibitory constituents of Euonymus alatus leaves and twigs on nitric oxide production in BV2 microglia cells. Food Chem. Toxicol. 2011, 49, 1394-1398. [CrossRef] [PubMed]

42. Pucci, C.; Martinelli, C.; Ciofani, G. Innovative approaches for cancer treatment: Current perspectives and new challenges. Ecancermedicalscience 2019, 13. [CrossRef] [PubMed]

43. Basli, A.; Belkacem, N.; Amrani, I. Health benefits of phenolic compounds against cancers. In Phenolic Compounds-Biological Activity; Intechopen: London, UK, 2017; pp. 193-210.

44. Kumar, S.; Pandey, A.K. Chemistry and biological activities of flavonoids: An overview. Sci. World J. 2013, 2013. [CrossRef] [PubMed]

45. Wang, J.; Yi, J. Cancer cell killing via ROS: To increase or decrease, that is the question. Cancer Biol. 2008, 7, 1875-1884. [CrossRef] [PubMed]

46. Wink, D.A.; Vodovotz, Y.; Laval, J.; Laval, F.; Dewhirst, M.W.; Mitchell, J.B. The multifaceted roles of nitric oxide in cancer. Carcinogenesis 1998, 19, 711-721. [CrossRef] [PubMed]

47. Snyder, C.M.; Shroff, E.H.; Liu, J.; Chandel, N.S. Nitric oxide induces cell death by regulating anti-apoptotic BCL-2 family members. PLoS ONE 2009, 4. [CrossRef] [PubMed]

48. Reveneau, S.; Arnould, L.; Jolimoy, G.; Hilpert, S.; Lejeune, P.; Saint-Giorgio, V.; Belichard, C.; Jeannin, J.-F. Nitric oxide synthase in human breast cancer is associated with tumor grade, proliferation rate, and expression of progesterone receptors. Lab. Investig. 1999, 79, 1215-1225. [PubMed]

49. Singleton, V.L.; Rossi, J.A. Colorimetry of total phenolics with phosphomolybdic-phosphotungstic acid reagents. Am. J. Enol. Vitic. 1965, 16, 144-158.

50. Mihailović, V.; Kreft, S.; Benković, E.T.; Ivanović, N.; Stanković, M.S. Chemical profile, antioxidant activity and stability in stimulated gastrointestinal tract model system of three Verbascum species. Ind. Crop. Prod. 2016, 89, 141-151. [CrossRef]

51. Park, Y.K.; Koo, M.H.; Ikegaki, M.; Contado, J.L. Comparison of the flavonoid aglycone contents of Apis mellifera propolis from various regions of Brazil. Braz. Arch. Biol. Technol. 1997.

52. Chang, C.L.; Lin, C.S.; Lai, G.H. Phytochemical Characteristics, Free Radical Scavenging Activities, and Neuroprotection of Five Medicinal Plant Extracts. Evid. Based Complementary Altern. Med. 2012, 2012. [CrossRef]

53. De Amorim, E.C.; de Castro, V.D.A.; de Melo, J.; Corrêa, A.; Sobrinho, T.D.S.P. Standard operating procedures (SOP) for the spectrophotometric determination of phenolic compounds contained in plant samples. In Latest Research into Quality Control; InTech: Rijeka, Croatia, 2012.

54. Mišić, D.; Šiler, B.; Gašić, U.; Avramov, S.; Živković, S.; Nestorović Živković, J.; Milutinović, M.; Tešić, Ž. Simultaneous UHPLC/DAD/(+/-) HESI-MS/MS analysis of phenolic acids and nepetalactones in methanol extracts of Nepeta species: A possible application in chemotaxonomic studies. Phytochem. Anal. 2015, 26, 72-85. [CrossRef]

55. Blois, M.S. Antioxidant determinations by the use of a stable free radical. Nature 1958, 181, 1199-1200. [CrossRef]

56. Oyaizu, M. Studies on products of browning reaction. Jpn. J. Nutr. Diet. 1986, 44, 307-315. [CrossRef]

57. Tusevski, O.; Kostovska, A.; Iloska, A.; Trajkovska, L.; Simic, S.G. Phenolic production and antioxidant properties of some Macedonian medicinal plants. Cent. Eur. J. Biol. 2014, 9, 888-900. [CrossRef] 
58. Dapkevicius, A.; Venskutonis, R.; van Beek, T.A.; Linssen, J.P. Antioxidant activity of extracts obtained by different isolation procedures from some aromatic herbs grown in Lithuania. J. Sci. Food Agric. 1998, 77, 140-146. [CrossRef]

59. Zengin, G.; Uysal, A.; Gunes, E.; Aktumsek, A. Survey of phytochemical composition and biological effects of three extracts from a wild plant (Cotoneaster nummularia Fisch. et Mey.): A potential source for functional food ingredients and drug formulations. PLoS ONE 2014, 9. [CrossRef]

60. Wan, L.-S.; Min, Q.-X.; Wang, Y.-L.; Yue, Y.-D.; Chen, J.-C. Xanthone glycoside constituents of Swertia kouitchensis with $\alpha$-glucosidase inhibitory activity. J. Nat. Prod. 2013, 76, 1248-1253. [CrossRef]

61. Ellman, G.L.; Courtney, K.D.; Andres, V., Jr.; Featherstone, R.M. A new and rapid colorimetric determination of acetylcholinesterase activity. Biochem. Pharm. 1961, 7, 88-95. [CrossRef]

62. Masuda, T.; Yamashita, D.; Takeda, Y.; Yonemori, S. Screening for tyrosinase inhibitors among extracts of seashore plants and identification of potent inhibitors from Garcinia subelliptica. Biosci. Biotechnol. Biochem. 2005, 69, 197-201. [CrossRef]

63. Mosmann, T. Rapid colorimetric assay for cellular growth and survival: Application to proliferation and cytotoxicity assays. J. Immunol. Methods 1983, 65, 55-63. [CrossRef]

64. Auclair, C.; Voisin, E. Nitroblue tetrazolium reduction. In Handbook of Methods for Oxygen Radical Research; BokaratonCrc Press: Boca Raton, FL, USA, 1985; pp. 123-132.

65. Griess, P. Bemerkungen zu der Abhandlung der HH. Weselsky und Benedikt "Ueber einige Azoverbindungen". Ber. Der Dtsch. Chem. Ges. 1879, 12, 426-428. [CrossRef]

Sample Availability: Samples E1, E2, and E4 of the H. cupressiforme are available, while the sample E3 is available at a smaller quantity from the authors.

(C) 2020 by the authors. Licensee MDPI, Basel, Switzerland. This article is an open access article distributed under the terms and conditions of the Creative Commons Attribution (CC BY) license (http://creativecommons.org/licenses/by/4.0/). 